\title{
The Carbonic Anhydrase as a Paragon: Theoretical and Experimental Investigation of Biomimetic Zinc-catalyzed Activation of Cumulenes
}

\author{
Burkhard O. Jahn, Wilhelm A. Eger and Ernst Anders \\ Friedrich-Schiller-University Jena \\ Germany
}

\section{Introduction}

Biomimetics as an interdisciplinary concept involves learning from and imitating of nature using appropriate models. The mimicry of biological models does not only consist of the construction of engineering systems and modern technology, furthermore, it is able to be a guide for designing and architecturing in the complete range of natural sciences. In particular, the actual development of novel and uncommon chemical reactions is aimed to apply high optimized, biochemical processes to laboratory and industrially usable syntheses. Especially enzymes stand in the visual focus as highly efficient and almost extreme specialized catalysts, as nature has had a long time to develop and optimize a wide diversity of life. Nearly every organism owns different tissues, motion types, sensoring functions and surviving instincts and the basis for all of these properties are highly efficient catalyzed chemical reactions. Organisms have not only to synthesize huge biopolymers for growth, but also to provide small molecules for signal transduction, energy transfers or regulation processes. Therefore, it is obvious that the study of those reactions not only gives insights in important biochemical processes, but also suggests new chemical pathways to use in synthesis or other related appliances. The possibilities of biomimetics in chemistry are outlined on the basis of the enzyme carbonic anhydrase. As this enzyme is one of the most efficient catalysts originated by nature, the investigation of such a catalytical active protein enriches not only the knowledge of biological and biochemical mechanisms and their mode of action, but also gives detailed information about the active center inside of the enzyme. In that way, one can fathom out important factors for the growth and development as well as for the investigation of diseases and glitches.

In this chapter we describe the enzymatic metal mediated reaction of the cumulene system carbon dioxide with water and its extention to the bio-analogue activation of further isoelectronic cumulenes (carbonyl sulfide, isothiocyanate and allene).

$$
\mathrm{CO}_{2}+\mathrm{H}_{2} \mathrm{O} \rightleftharpoons \mathrm{HCO}_{3}^{-}+\mathrm{H}^{+} \rightleftharpoons \mathrm{H}_{2} \mathrm{CO}_{3}
$$

Most of the theoretical (DFT calculations) and experimental results were obtained by the authors of this chapter or in direct collaboration with former members of the Jena group (Dr. Stephan Schenk, Dr. Johannes Notni) and other researchers: Prof. Dr. Jürgen Kesselmeier (Mainz, Germany), Prof. Dr. Heinrich Vahrenkamp (Freiburg, Germany), Prof. Dr. Eckhard 
Dinjus and Prof. Dr. Manfred Doering (Karlsruhe, Germany), Prof. Dr. Wolfram Koch (Frankfurt, Germany), Prof. Dr. James Weston (La Plata, Argentina), Prof. Dr. Detlef Schröder (Prag, Czech), Prof. Dr. Helmut Schwarz (Berlin, Germany), Prof. Dr. Andrea Bottoni (Bologna, Italy) and Dr. Sten Nilsson Lill (Göteborg, Sweden). We made significant efforts to cite the relevant contributions by others; nevertheless, the discussion of their results will be very brief in order to keep this chapter within a reasonable length.

\section{The Model Enzyme Carbonic Anhydrase}

Carbonic anhydrases (CA) are an ancient enzyme class most likely as old as life on earth. As every organism contains CA, they might be one of the most important enzyme classes. Naturally, these enzymes catalyze the reversible reaction of carbon dioxide with water to bicarbonate (see equation 1 ). They belong to the enzyme class of lyases, which generally catalyzes the cleavage of molecules.

At present all CAs are divided into six classes ( $\alpha-\zeta$ class). All classes developed independently and therefore are examples of convergent evolution (Hewett-Emmett \& Tashian, 1996). The representatives of the $\alpha$ class are found in all mammalians and can be subdivided into currently fifteen isoforms. Depending on the individual structure, each isoform fullfills other specialized tasks in biochemical processes. The isoform CA-I was identified in erythrocytes (Lowe et al., 1990) and is the mostly spread protein beside of globuline and responsible for the conversion of the badly water soluble gas carbon dioxide into bicarbonate, which is completely soluble and hence better transportable in water. For this reason CA-I is the base for efficient respiration. CA-II, which is one of the most active isoforms, owns turn over numbers near the diffusion controlled limit $\left(k_{c a t}=620000 \mathrm{sec}^{-1}\right)$ (Gibbons \& Edsall, 1964) and an acceleration factor of $10^{7}$ compared to the uncatalyzed reaction (Lindskog, 1997). Deficiency of CAII leads to osteopetrosis with renal tubular acidosis and cerebral calcification (Sly et al., 1983). While CA-IV is involved in the ionic transport mechanisms in the endothel of the cornea (Sun et al., 2008), CA-V is placed in the mitochondria and used as a supplier for $\mathrm{HCO}_{3}^{-}$in the urea cycle (Dodgson \& Forster, 1986). CA-VII and CA-VIII are involved in neuronal signal forwarding and the provision of neurotransmitters in the central nervous system (Ruusuvuori et al., 2004; Yan et al., 2007). Another point of interest is the role of CAs in the development of cancer, as the activity of CA-IX and CA-XII could be proven in several tumor cells and tissues, for example breast, kidney or cerebral cancer (Barnett et al., 2008; Brennan et al., 2006; Chrastina et al., 2003; Jarvela et al., 2008).

\subsection{Insights into the Enzymatic Mechanism}

All CAs contain one zinc(II) cation as a cofactor (Keilin \& Mann, 1939) with the exception of $\zeta$-CAs, which possess a diatomic metal center. The central metal is not constricted to zinc in those CAs due to low zinc concentrations in the habitat of organisms containing them (Lane et al., 2005). In the catalytic core of $\alpha$-class CAs the zinc ion is complexed by three histidine amino acid residues (His94, His96, His119) and a water or rather hydroxide ligand depending on the intracellular $p H$ value (see Figure 1).

After getting into the hydrophobic pocket, $\mathrm{CO}_{2}$ becomes immobilized by a hydrogen bridging bond to Thr199, which plays the role of a gatekeeper to the active center. The zinc bound hydroxide ion then initiates the hydrolysis by a nucleophilic attack on $\mathrm{CO}_{2}$. In the following step the produced bicarbonate is displaced by a water molecule, which is subsequently deprotonated by the help of a proton relais to His64 to give zinc bound hydroxide for the next 


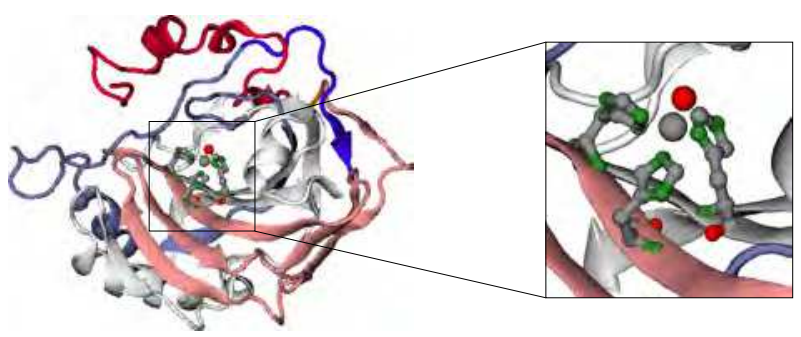

Fig. 1. An X-ray structure of CA-II depicted as a ribbon model (Eriksson et al., 1988). In the representation of the active center hydrogens are not displayed.

turn of catalysis. This relais shuttle consists of several intra- and intermolecular proton shifts in a row.

The step between the nucleophilic attack and the replacement of bicarbonate was the topic of a controversial discussion in the past. While Lipscomb et al. (Liang \& Lipscomb, 1987; Lipscomb, 1983) favored a proton shift between the two oxygens, the direct coordination by an oxygen and a rotation step was postulated by Lindskog et al. (Lindskog, 1984; 1997). In fact, depending on the complexness of the used model and the used quantumchemical methods respectively, each mechanism can be the favored one. Additionally, the exchange of bicarbonate for water can occur without direct coordination of an oxygen of $\mathrm{CO}_{2}$ (see Figure 2). For further mechanistic aspects see (Mauksch et al., 2001).

As the electronic configuration of the zinc(II) cation has a closed $3 \mathrm{~d}$ shell, which is very stable, zinc compounds contain this ion nearly without any exception. Additional results of this stable state are a fairly low redox activity of the zinc(II) ion, no stabilization of the ligand field and a wide range of coordination numbers going from two to eight.

\subsection{Design of Biomimetic Chemical Models}

The properties of a capable model describing the biomimetics of CA depend significantly on the aim of the application. Firstly, it is important, whether the model is used in an experimental environment or for theoretical purposes, and secondly, it depends on the goal of examination.

At least a model for simulating the catalytic core of CA needs an appropriate ligand sphere and an additional nucleophilic ligand, so one of the most simplified models is the $\left[\mathrm{Zn}\left(\mathrm{NH}_{3}\right)_{3} \mathrm{OH}\right]^{+}$complex (see Figure 3).

\subsubsection{Model for Computational Purposes}

This model is only suitable for theoretical aspects, as it is not stable in solution and consists beside the zinc ion and the hydroxide ligand only of three ammonia ligands, which are a simplification of the histidine amino acid ligand sphere. Nevertheless, the so called ammonia model fulfills the needs of a theoretical model very well. One major aspect regarding calculations in chemistry is the number of atoms in the molecule. As the computation time correlates to the number of atoms like $\mathrm{N}^{3}$ for density functional theory (DFT) and $\mathrm{N}^{5}$ or $\mathrm{N}^{6}$ for PostHartree-Fock (ab initio) methods, it is important to keep the molecule as small as possible for efficient calculations.

The second major aspect of choosing a model for computational chemistry is its ability to describe the geometric and electronic properties of a molecule as exact as possible in comparison 


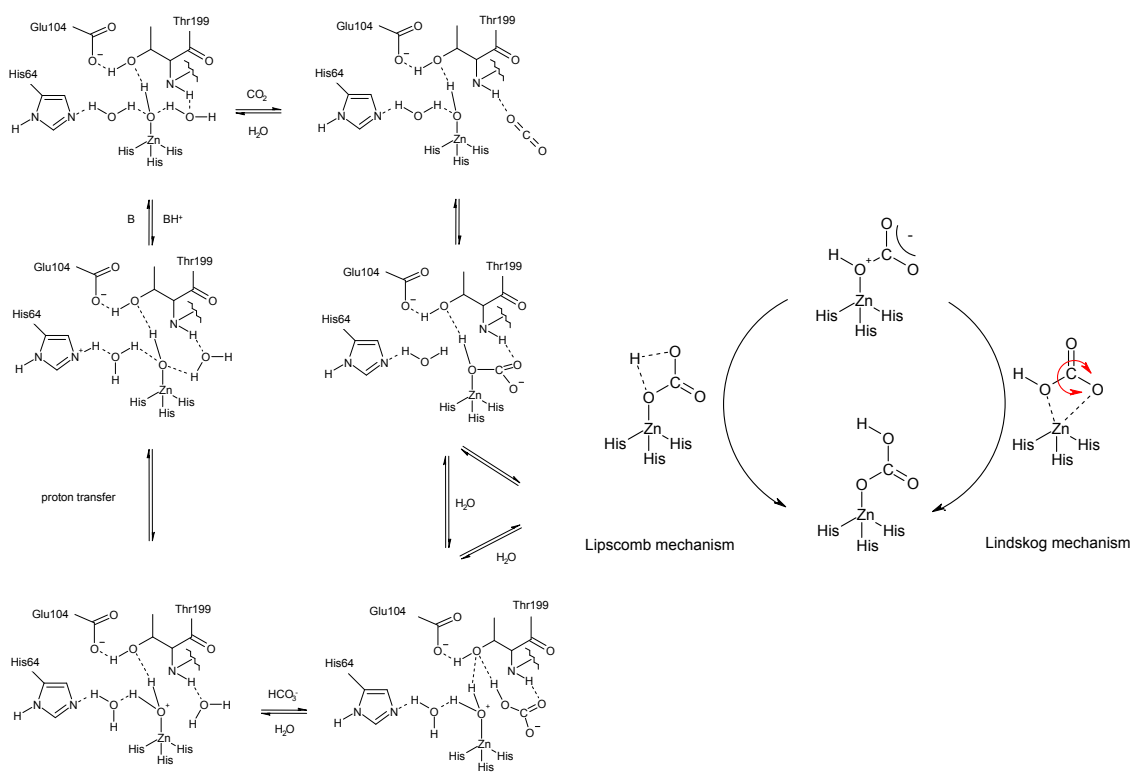

Fig. 2. Postulated enzymatic mechanism for $\alpha$-CAs including the Lindskog and Lipscomb variants (Bertran et al., 1992; Krishnamurthy et al., 2008).

to reality. Describing the reaction in the real enzyme, it is better to have a bigger system, which also pays attention to parts of the peptidic backbone and its role in the mechanistic pathway. A good choice for this aim is the model of Bottoni et al. (Bottoni et al., 2004), which includes the mechanisticly important amino acid residues Glu106 und Thr199 (see Figure 3). If it is the aim to apply the biomimetic principle to a model in synthesis, it is important to have a stable and simple molecule, what provides the basic features of the catalytic core. Depending on the reaction, the nucleophilic ligand can be varied, e. g. to a thiolate ligand.

As this chapter describes the transfer of the biomimetic principles from the enzyme CA to a model used in synthesis, the Bottoni model is not appropriate. Beneath the ammonia model one can imagine a more complex one containing imidazole rings instead of ammonia ligands. Although it resembles the ligand sphere in the catalytic core of CA better, it is not worth the calculational effort. Firstly, the imidazole rings in the enzyme have a fixed position, whereas they can turn in the model, and secondly, they do not have any significant influence on the electronic situation at the nucleophilic part of the model compared to an ammonia ligand sphere (see Table 1).

The natural charges of the ammonia model are also very similar to those calculated for the model bearing a [12] $\mathrm{aneN}_{3}$ ligand (see Table 1). Contrary to the model using imidazole ligands, the ammonia and the [12] $\mathrm{aneN}_{3}$ model possess amino functions directly connected to the metal center, so the ammonia ligand sphere would resemble the situation at the [12]aneN $\mathrm{N}_{3}$ complex better than the imidazole model. Keeping all these arguments in mind the ammonia complex is the appropriate model for our purposes. It is small and therefore can be calculated very quickly, and it is accurate enough for transferring the biomimetic principle from the catalytic core to a certain complex in synthesis. The ammonia model has already proved 


\begin{tabular}{lccc}
\hline model & $\mathrm{Zn}$ & $\mathrm{O}$ & bond length $[\AA]$ \\
\hline human CA-II & +1.66 & -0.99 & 1.878 \\
ammonia & +1.62 & -1.32 & 1.849 \\
imidazole & +1.65 & -1.31 & 1.879 \\
[12]aneN $_{3}$ & +1.61 & -1.31 & 1.851 \\
Bottoni & +1.63 & -1.32 & 1.910
\end{tabular}

Table 1. Natural charge distribution and $\mathrm{Zn}-\mathrm{O}$ bond lengths in several CA models (calculated at the B3LYP / 6-311+G(d,p) level) in comparison to the native CA.

its efficiency in extensive theoretical investigations (Bräuer et al., 2002; Eger et al., 2009; Jahn et al., 2008; Mauksch et al., 2001; Schenk et al., 2004; Schröder et al., 2003; Sinnecker et al., 2001) and serves as the structural fundament for examining reaction pathways in case of CA.

\subsubsection{Model for Experimental Purposes}

In the last fifty years a lot of zinc complexes were synthesized with the aim to create a good CA simulating model. Some of them are depicted in Figure 3. Beneath the nucleophilic residue, the ligand is responsible for almost all properties of the complexes like solubility, complex stability and structure. But it also has a significant effect on the catalytic effectivity of the model, as it defines the geometry in the close vicinity of the nucleophilic ligand. Most of the synthesized ligands have either a tripodal or macrocyclic geometry (see Figure 3 ). To the variety of ligands used for modelling CA belong tris(2-benzimidazolylmethyl)amine (BIMA) (Brandsch et al., 1997; Echizen et al., 2004; Nakata et al., 1997), different azamacrocycles, such as 1,5,9-triazacyclododecane ([12]aneN ${ }_{3}$ ) (Kimura et al., 1990; Richman \& Atkins, 1974), further tris(imidazolyl)carbinole (TIC) (Tang et al., 1978), tris(imidazolyl)phosphane (TIP) (Kunz et al., 2003), 1,3,5-triaminocyclohexane (tach) (Bowen et al., 1996; Cronin et al., 1996; Cronin \& Walton, 2003; Urbach et al., 1968) and the representatives of hydrotris(pyrazolyl)borates (Tp) (Trofimenko, 1966; 1967; Yang et al., 1995), tris(pyrazolyl)methanes (Tpm) (Sánchez-Méndez et al., 2004; Zvargulis et al., 1995) or tris(pyrazolyl)methanesulfonates (Tpms) (Kläui et al., 2000).

In general, complexes containing a macrocyclic ligand possess a higher complex constant and thus are more stable, this is a result of the macrocyclic effect. Common macrocyclic ligands are cyclic azaethers e.g. cyclen ([12]aneN $\mathrm{N}_{3}$ ) and cyclam ([12]ane $\left.\mathrm{N}_{4}\right)$, whereas cyclam does not simulate the ligand sphere of CA very well, but surprisingly has better reaction rates then cyclen. With a $p K_{a}$ of $7.3\left[\mathrm{Zn}\left([12] \mathrm{aneN}_{3}\right) \mathrm{OH}\right]^{+}$is very close to the $p K_{a}$ value of CA-II (about 7), whereas [ $\left.\mathrm{Zn}\left([12] \mathrm{aneN}_{4}\right) \mathrm{OH}\right]^{+}$shows a $p K_{a}$ value about 8.1 (Riccardi \& Cui, 2007; Zhang \& van Eldik, 1995). In aqueous solution, these complexes exist in a $p H$ dependent equilibrium with their protonated forms, $\left[\mathrm{Zn}\left([12] \mathrm{aneN}_{\mathrm{X}}\right) \mathrm{OH}_{2}\right]^{2+}$. Zinc hydroxide complexes of such three- and four-dentate azacycloalkanes react with $\mathrm{CO}_{2}$ to bi- resp. mono-dentate hydrogencarbonate complexes (Schrodt et al., 1997). As $\left[\mathrm{Zn}\left([12] \mathrm{aneN}_{4}\right) \mathrm{OH}\right]^{+}$coordinates this substrate only on one coordination point, van Eldik et al. postulated this complex to be a better CA simulating model. The azacycloalkane based models form a bridge between theory and experiment due to their easy access in synthesis and good usability for quantumchemical calculations. For a model describing the active center of CA, some criteria regarding the $K_{D}$ value have to be fulfilled (Parkin, 2000; 2004). The $K_{D}$ value for CA-II was measured at $K_{D}=4 \mathrm{pM}(p H=7)$, 
what is important to prevent the metal and the ligand from dissociating, and therefore the presented models are appropriate, as they reach $K_{D}$ values in the nanomolar range.

Another thoroughly investigated ligand family consists of tripodal trispyrazolyl ligands bearing either a carbon or a boron atom and trisimidazolyl ligand respectively bearing a carbon or a phosphor atom. These complexes also have very good complex constants and they allow creating different reaction pockets by varying the residues of the pyrazole and imidazole rings. The creation of such hydrophobic pockets avoids the multiple complexation of the ligand by the zinc ion. Contrary to the macrocyclic complexes those compounds can occur as neutral or cationic complexes depending on the element used at the tripodal position. The formation of cationic complexes is of importance for correctly modelling the catalytic centre of CA. The application of a charged ligand would necessarily result in a model system that does not reflect the electronic properties of the active site.

Summarizing this, both model concepts - azamacrocyclic and tripodal ligands - are appropriate to be used to apply the reaction principle of CA as chemical biomimetics to develop new syntheses. Although they have a lot in common, the differences between them define the cases they can be used in. As the azamacrocyclic complexes do not possess a hydrophobic pocket around the nucleophilic ligand, they provide a better accessibility of the catalytic center. This might be interesting when reacting bulky substrates. But the absence of this pocket gains a disadvantage as not all complexes are stable. In particular the hydrosulfide and alkyl thiolate complexes are not available. As there exist not only three- but also four-dentate azamacrocyclic ligands, the corresponding complexes can also be used to simulate the biomimetics of human CA-II. Zinc complexes of cyclic azaethers possess very high complex constants because of the macrocyclic effect, so they can be used under very harsh conditions without getting destroyed.

In comparison, tripodal ligands can not only simulate a hydrophobic pocket, but provide the possibility to measure the reaction rates depending on the size and composition of it. Depending on the element used at the tripodal position, they are neutral or cationic systems. Thus some tripodal ligands provide complexes, which are independent of dealing with an counterion.

\section{Details about the Quantumchemical Calculations}

In analogy to preceding investigations on the mode of action of CA, we used density functional theory (DFT) calculations to propose a mechanism. All calculations were realized using the Gaussian 03 (Frisch et al., 2004) program package, whereas Natural Bond Orbital (NBO) analyzes were performed using NBO 5.0 (Glendening et al., 2001). Stable structure geometries were characterized by a frequency calculation, in which energetic minima must not have a imaginary mode, whereas the presence of exactly one imaginary frequency characterizes a transition state. The visualization of this mode normally illustrates the reaction path, but in several cases an intrinsic reaction coordinate (IRC) calculation is appropriate to verify the correct products and educts corresponding to a transition state.

\section{Carbonyl Sulfide (COS), an Important Atmospheric Trace Gas}

For a better understanding, in this part of our chapter we additionally will give a few explanations of the biological backgrounds. Due to the enormous catalytic effect of CA, almost all living organisms use these enzymes for important $\mathrm{CO}_{2}$ exchange processes with the atmosphere. However, it is less well known that CA is also involved in the fixation of the atmo- 

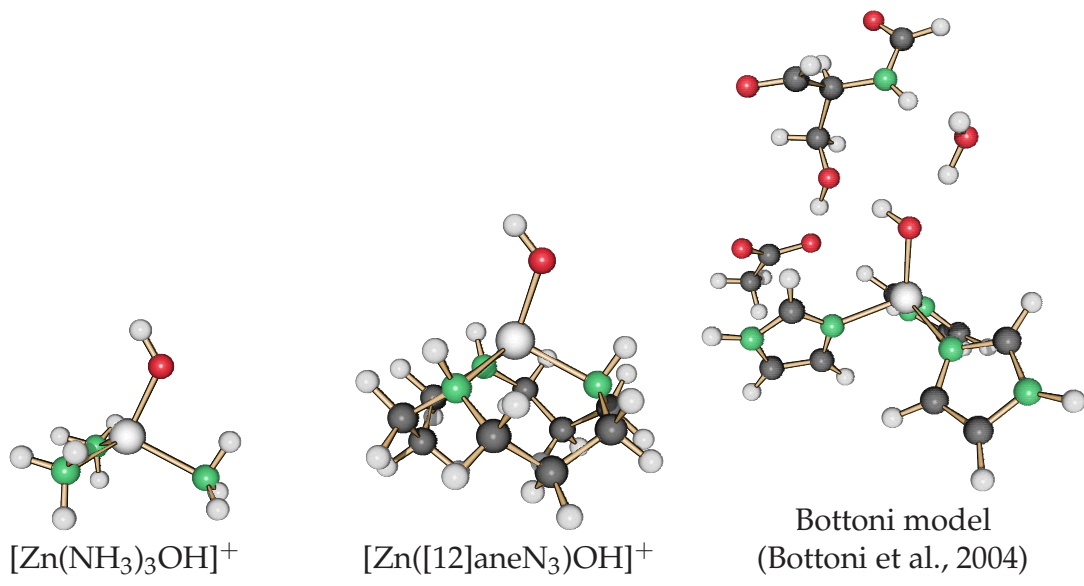

Bottoni model

(Bottoni et al., 2004)<smiles>c1ccc2[nH]c(CN(Cc3nc4ccccc4[nH]3)Cc3nc4ccccc4[nH]3)nc2c1</smiles>

BIMA<smiles>[R]c1nc(C(O)(c2nc([R])[nH]c2C)c2nc([R])[nH]c2C)c(C)[nH]1</smiles>

TIC<smiles></smiles>

$\mathrm{Tp}$<smiles>C1CCNCCNCCNC1</smiles>

[12]aneN 4<smiles>C1CNCCCNCCNC1</smiles>

[12]aneN 3<smiles>[R]c1nc(P(c2nc([R])[nH]c2C)c2nc([R])[nH]c2C)c(C)[nH]1</smiles>

TIP<smiles>[R]c1cc(C)n(C(C(n2nc([R])cc2C)n2nc([R])cc2C)n2nc([R])cc2C)n1</smiles>

Tpm<smiles>NC1CC2CN(N)CC(C1)N2</smiles>

tach<smiles>[R]c1cc(C)n(C(C)(n2nc([R])cc2C)n2nc([R])cc2C)n1</smiles>

Tpms

Fig. 3. Selection of possible CA models as well as several ligands used to construct CA simulating complexes. 


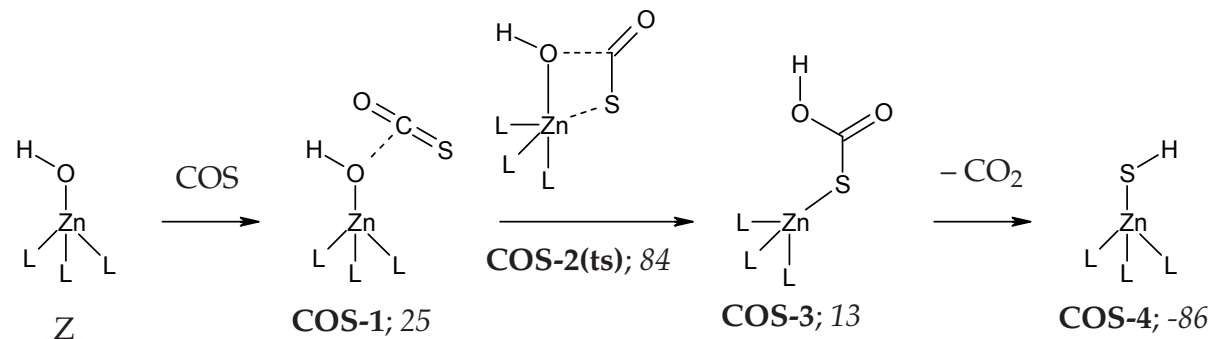

Fig. 4. Calculated mechanism of the fixation of COS, calculated at the B3LYP/6-311+G(d,p) level of theory (free energy values given in $\mathrm{kJ} / \mathrm{mol}$ ).

spheric trace gas carbonyl sulfide (COS) (Sandoval-Soto et al., 2005). As more recently and thoroughly investigated, COS is the most stable reduced sulfur compound in the atmosphere with a lifetime of 1-7 years. CA plays a significant role in the regulation of COS in the atmosphere and in the global distribution of sulfur (Schenk et al., 2005). Interestingly, it contributes indirectly to the global climate due to the fact that degradation of COS accounts for sulfate particles in the stratospheric aerosol layer which reflects solar radiation. Its main sources are the oceans where it is thought to be generated by photooxidation of sulfur-containing amino acids. Main sink for COS is the vegetation. The consumption of COS by many organisms, such as higher plants, algae, and lichens (Kuhn \& Kesselmeier, 2000), was found to be CAdependent. Furthermore, CA plays an important role in the interpretation of toxicity of COS. During COS consumption, $\mathrm{H}_{2} \mathrm{~S}$ is formed, which has been recognized almost thirty years ago as being the actual toxin responsible for the noxious effect of this heterocumulene (Chengelis \& Neal, 1980). This has been confirmed by the finding that inhibition of CA lowers the mortality of insects upon exposition to COS, by lowering the rate of hydrolysis. In addition, CA-dependence of $\mathrm{H}_{2} \mathrm{~S}$ formation upon $\mathrm{COS}$ consumption has been proven for the example of algae. It can therefore be considered as being accepted that COS is a natural substrate of CA, which catalyzes its irreversible hydration according to equation 2 .

$$
\mathrm{COS}+\mathrm{H}_{2} \mathrm{O} \rightarrow \mathrm{CO}_{2}+\mathrm{H}_{2} \mathrm{~S} .
$$

The mechanism of this CA-catalyzed COS fixation according to Figure 4 has been investigated by some of us using the established computational ammonia model (Schenk et al., 2004). The reaction follows the same principle as the $\mathrm{CO}_{2}$ reaction. The attack of the zinc-bound hydroxide occurs exclusively at the $\mathrm{C}=\mathrm{S}$ bond and results in a four-centre transition structure COS2(ts), whereby a zinc-bound thiocarbonate COS-3 is formed. Although this structure could not be observed in an experimental investigation until now, there is more than circumstantial evidence for its intermediate existence based upon our detailed calculations and related structures observed in experiments. By a water-assisted proton transfer, $\mathrm{CO}_{2}$ is formed which is expelled and the zinc hydrosulfide complex COS-4 is obtained. This species is stabilized by a strong $\mathrm{ZnS}$ bond. As a consequence, we initially assumed that the enzyme must be deactivated by this reaction. However, this contradicts the generally accepted finding that in the course of $\mathrm{COS}$ fixation $\mathrm{H}_{2} \mathrm{~S}$ is formed (Blezinger et al., 2000). Furthermore, we detected an interesting side path in this reactions cascade: A water molecule helps to regenerate the original zinc hydroxide complex from the hydrosulfide complex COS-4 and the formation of $\mathrm{H}_{2} \mathrm{~S}$. Nevertheless, at the beginning of our investigations the mode of reactivation of the catalytic 


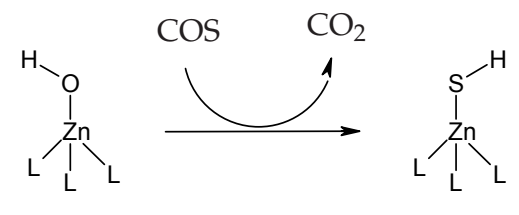

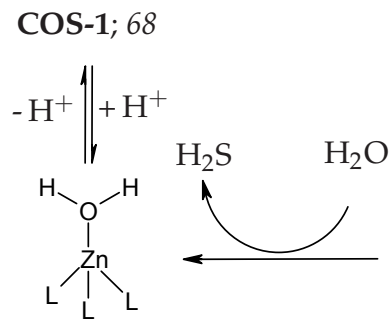

COS-6; 10
COS-4;0

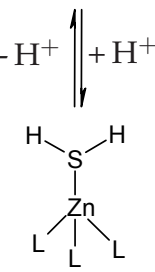

COS-5; 31

Fig. 5. Transformation of COS by the CA model complex $\left[\mathrm{Zn}\left([12] \mathrm{aneN}_{3}\right) \mathrm{OH}\right]^{+}$and mechanism of regeneration of the catalytic domain, calculated at the C-PCM(B98/G3Large)//C$\mathrm{PCM}(\mathrm{B} 3 \mathrm{LYP} / 6-311+\mathrm{G}(\mathrm{d}, \mathrm{p})$ ) level of theory (free energy values given in $\mathrm{kJ} / \mathrm{mol}$ relative to COS-4)

domain of the hydrosulfide analogue of CA was an open question, which is of special interest since some organisms apparently utilize this $\mathrm{H}_{2} \mathrm{~S}$ production process and some additional reactions steps as their only source of sulfur (Kuhn \& Kesselmeier, 2000).

In case the organism is growing in sulfate-rich environment, it necessarily will not require the sulfide that stems from COS fixation. The sulfur will then be expelled in form of $\mathrm{H}_{2} \mathrm{~S}$, since this is the main process plants utilize to free themselves from excess sulfur of any origin (Saito, 2004). However, plants which grow on sulfate deficient soils actually depend on atmospheric sources of sulfur. $\mathrm{H}_{2} \mathrm{~S}$ and particularly $\mathrm{SO}_{2}$ are commonly considered as being the most important atmospheric sulfur compounds taken up by plants (Bertini et al., 1985). Nonetheless, in some areas where the atmospheric supply of these compounds is to low to meet the requirement of plants, $\mathrm{H}_{2} \mathrm{~S}$ formed by the COS metabolism becomes an important factor. We thus elucidated a possible mechanism for the final step of this process in order to achieve its complete understanding also at a molecular scale.

As explained above and depicted in the scheme in Figure 4, the active catalyst $\mathbf{Z}$ reacts with COS and is transformed into the zinc hydrosulfide COS-4 (stabilized by $68 \mathrm{~kJ} / \mathrm{mol}$ ) (Schenk et al., 2004). Protonation resulting in the hydrogen sulfide complex COS-5 requires only $31 \mathrm{~kJ} / \mathrm{mol}$. It can thus be assumed that COS-4 should be protonated at least to a small extent. The replacement of $\mathrm{H}_{2} \mathrm{~S}$ by a water molecule is now enforced by two effects: First, the aquo complex COS-6 is stabilized by $21 \mathrm{~kJ} / \mathrm{mol}$ which is hardly surprising in view of the exceptionally weak coordination of $\mathrm{H}_{2} \mathrm{~S}$ ligands to zinc centres. Second, the dissociation of hydrogen sulfide is practically irreversible due to the fact that its concentration in the surrounding medium is negligible compared to water. The irreversibility of this ligand exchange ensures that all zinc-bound sulfur is eventually expelled, since the hydrosulfide protonation equilibrium (see equation 3) provides a small but constant amount of the neutral $\mathrm{H}_{2} \mathrm{~S}$ ligand which can easily dissociate. 


\section{$\mathrm{COS}-4 \leftrightharpoons \mathrm{COS}-5$}

As a consequence, the protonation of COS-4 is the rate-determining step of the desulfuration reaction. Of course, this process is likely to proceed quite slowly. However, a minute overall reaction rate should be sufficient: due to the extraordinarily small atmospheric COS concentration, sulfur analog CA is present in only very small amounts. A fast regeneration is therefore not required. The final deprotonation of the intermediate COS- 6 results in the catalyst COS-1, which, according to our calculations, is endergonic by $58 \mathrm{~kJ} / \mathrm{mol}$. This deprotonation has already been extensively discussed in the context of CA-catalyzed $\mathrm{CO}_{2}$ fixation since it is the initial step in generation of the active site, i. e. a representative of this interesting class of nucleophilic cations for which CA is the natural paragon.

\subsection{In vitro experimental investigations}

Some years ago, a model reaction has been performed by Vahrenkamp and some of us which exemplifies the process of COS fixation (Bräuer et al., 2002). The trispyrazolylborato zinc hydroxide complex $\mathrm{Tp}^{\mathrm{Ph}, \mathrm{Me}} \mathrm{ZnOH}$ has been applied as the CA model (Notni, Schenk, ProtoschillKrebs, Kesselmeier \& Anders, 2007). It has been reacted with COS, whereby $\mathrm{CO}_{2}$ and the corresponding hydrosulfide complex $\mathrm{Tp}^{\mathrm{Ph}, \mathrm{Me}} \mathrm{ZnSH}$ comparable to COS-4 were formed (see Figure 5). In contrast to the $\left[\mathrm{Zn}\left([12] \mathrm{aneN}_{3}\right)\right]^{2+}$ system, the $[\mathrm{TpZn}]^{+}$moiety is stable enough to bear a hydrosulfide ligand. The $\mathrm{Tp} \mathrm{p}^{\mathrm{Ph}, \mathrm{Me}} \mathrm{ZnOH}$ complex is thus excellently suited for modelling the calculated regeneration mechanism, particularly with regard to the similar deprotonation enthalpies encountered for the related trispyrazolylborato and azamacrocyclic complexes. At neutral $p H$, the reaction cascade stops at the stage of the hydrosulfide (COS-4). However, after repeating this reaction, we recently could demonstrate that at $p H$ values below 4 the hydrosulfide ligand is apparently protonated. Upon treatment of trispyrazolylborato complex of COS-4 with small portions of $\mathrm{HClO}_{4}, \mathrm{H}_{2} \mathrm{~S}$ is formed, which can be removed from the solution by an argon stream. Since the trispyrazolylborato ligand is hydrolyzed at very low $p H$, the reaction mixture has to be kept at $p H=3$ or above, which requires constant measurement and dropwise addition of $\mathrm{HClO}_{4}$.

Further contributions to this subject have been made by Carrano et al. (Hammes et al., 2002) and Parkin et al. (Bergquist et al., 2003), both of whom isolated and characterized different examples of the $\left[\mathrm{TpZnOH}_{2}\right]^{+}$structure type with various anions. The latter authors have also shown that addition of base deprotonates the aquo ligand. From all these works with the trispyrazolylborato ligand, we derive the assumption of intermediate existence of the cation COS-6. We subsequently recovered the hydroxide complex COS-1 from the alkalized solution of COS-6 and identified it by NMR spectroscopy.

\subsection{In vivo experimental investigations}

The release of $\mathrm{H}_{2} \mathrm{~S}$ from cleavage of $\mathrm{COS}$ was investigated with the green alga Chlamydomonas reinhardtii as this organism contains extracellular CA localized on its outer cell membranes faced to environmental solution. Hence, the released $\mathrm{H}_{2} \mathrm{~S}$ can be expected to escape the biological metabolism quite easily. As shown in Figure 6, the release $\mathrm{of}_{2} \mathrm{H}_{2} \mathrm{~S}$ is closely correlated to the consumption of COS but a substantial part of the expected $\mathrm{H}_{2} \mathrm{~S}$ is always missing. We assume either a metabolic consumption of $\mathrm{H}_{2} \mathrm{~S}$ and /or a loss of $\mathrm{H}_{2} \mathrm{~S}$ due to the technical needs using a headspace technique. The latter instance is most probable, as it is known that application of this technique may involve a loss of 30 to $40 \%$ of the $\mathrm{H}_{2} \mathrm{~S}$ formed. A similar release of $\mathrm{H}_{2} \mathrm{~S}$ upon $\mathrm{COS}$ consumption could be reported for marine algae, although 


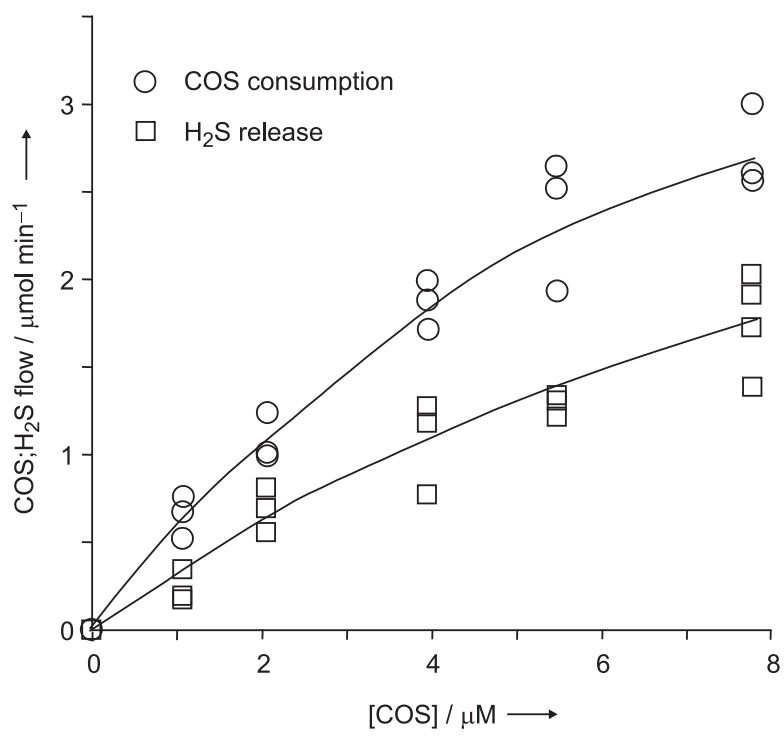

Fig. 6. COS consumption and $\mathrm{H}_{2} \mathrm{~S}$ production in correlation to increasing COS concentrations by the green alga Chlamydomonas reinhardtii grown under $0.03 \% \mathrm{CO}_{2}$. Amount of algae

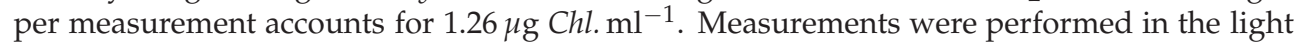
with $5 \mathrm{~W} / \mathrm{m}$ in $25 \mathrm{~mm}$ barbital buffer at $p H=7.5$. COS and $\mathrm{H}_{2} \mathrm{~S}$ in aqueous solutions were determined by a dynamic headspace technique coupled to GC-FPD analysis.

on significant lower activity levels which can be discussed as being caused by missing extracellular CA.

\subsection{Discussion of the DFT calculations: Experiment meets theory}

A DFT-calculation which is related to those presented in this work has been reported earlier by Parkin and coworkers (Bergquist et al., 2003). They investigated the deprotonation of a complex of the $\left[\mathrm{TpZnOH}_{2}\right]^{+}$type according to equation 4.

$$
\left[\mathrm{TpZnOH}_{2}\right]^{+} \rightleftharpoons[\mathrm{TpZnOH}]+\mathrm{H}^{+}
$$

For this reaction, they calculated a free energy of $1172 \mathrm{~kJ} / \mathrm{mol}$. This is substantially different to the deprotonation energy value we obtained for the zinc-bound water of the azamacrocyclic compound COS-5 $(58 \mathrm{~kJ} / \mathrm{mol})$. Although we used another model system, the energies should at least be of the same order of magnitude. Presumably, the difference results from the fact that in equation 4 , the free energy of the proton has been set to zero by these authors. However, for calculations including solvent effects, the solvation free energy of the proton should be taken into account to obtain realistic deprotonation energies. For the total free energy of the proton in aquatic solution, we used a value of $1125 \mathrm{~kJ} / \mathrm{mol}$ given in the literature. This value is the sum of the absolute free energy of the proton in the gas phase $(26 \mathrm{~kJ} / \mathrm{mol})$ and its absolute solvation free energy $(1099 \mathrm{~kJ} / \mathrm{mol})$. When this free energy value is added to the free energy of deprotonation reported by Parkin et al., a corrected value of $47 \mathrm{~kJ} / \mathrm{mol}$ is obtained. This is in very good agreement with our result. We therefore conclude that the selection of two 
apparently completely different model systems, one with an azamacrocyclic and the other with a pyrazolyl type ligand, is not a problem. Apparently, the deprotonation energies of the zinc-bound water are very similar. Thus we assume that our experiment using the TpZnSH complex is suited to corroborate and illustrate the calculated mechanism. Although a true catalysis is not observed, the substrate $\mathrm{COS}$ can be transformed into $\mathrm{CO}_{2}$ and $\mathrm{H}_{2} \mathrm{~S}$ in the presence of $\mathrm{Tp} \mathrm{p}^{\mathrm{Ph}, \mathrm{Me}} \mathrm{ZnOH}$ just by altering the $\mathrm{pH}$ of the solution.

According to our calculations, the protonation free energies of the zinc-bound hydroxide and hydrosulfide differ by ca. $84 \mathrm{~kJ} / \mathrm{mol}$. This is in good agreement with our experimental observation that a fast desulfuration occurs only at $p H$ values at which a zinc-bound water is not deprotonated. Nevertheless, a well-balanced $p H$ at the active site of natural CA could allow both a predominantly deprotonated zinc-bound water ligand and small but sufficient protonation of the zinc-bound hydrosulfide. As we already pointed out above, we hold the view that a small amount of protonated hydrosulfide ligand at the zinc ion is sufficient for complete desulfuration of CA due to the fact that the dissociation of $\mathrm{H}_{2} \mathrm{~S}$ is practically irreversible. In our opinion, the calculated mechanism is thus very likely to occur the way it is depicted in Figure 5.

The role of other amino acid residues in the catalytic mechanism has been addressed in studies by Bottoni (Bottoni et al., 2004) and Liedl (Tautermann et al., 2003). They have demonstrated that some of the residues, especially Glu106 and Thr199, are directly involved in some steps of the $\mathrm{CO}_{2}$ fixation. It has also been commented upon that a histidine residue in the enzyme cavity near the active site (so-called proton shuttle) influences the $p K_{a}$ of the zinc-bound water. The residue which is located in a distance of approx. $7 \AA$ from the zinc centre can be present in both protonated or deprotonated state. For both cases, different $p K_{a}$ values for the zinc-bound water have been measured (Bertini et al., 1985). It is very probable that its protonation state will also affect a zinc-bound hydrosulfide ligand. However, the conclusions drawn in all these studies did not introduce any change in the overall qualitative picture obtained with simpler models that neglect those amino acids. We hold the view that in order to exactly calculate such effects, an expanded model system taking into account the additional residues and a study of molecular dynamics would be required. This would currently exceed by far the computational resources available to us. In addition, we do not believe that such calculation would substantially alter the proposed mechanism. Our aim was to deliver the proof of principle for the hypothesis that hydrosulfide substitution of CA does not entail inhibition of the enzyme, and nothing but a water molecule is required for reactivation and formation of $\mathrm{H}_{2} \mathrm{~S}$. We are sure that this proposal is sufficiently supported by our model calculations and experiment. From the in vivo experiments, it is obvious that there is a correlation between COS consumption and $\mathrm{H}_{2} \mathrm{~S}$ release. As stated above, the missing amount of $\mathrm{H}_{2} \mathrm{~S}$ flow is not a problem since systematic errors in experiment and partial $\mathrm{H}_{2} \mathrm{~S}$ metabolisation have been shown to be possible reasons for this finding. However, the most important observation is that there is apparently no deactivation of CA by COS: With increasing COS concentration, the plot of the $\mathrm{H}_{2} \mathrm{~S}$ release rates shows no signs of any saturation effects, i. e. non-proportionality to the COS consumption plot. This fact strongly corroborates the overall statement of this study.

\section{Application of the Enzymatic Reaction Principle to further Examples of Isoelec- tronic Molecules}

As seen in the sections above, the reaction principle of $\mathrm{CA}$ is not restricted to the molecule $\mathrm{CO}_{2}$ but has been applied to COS by nature itself. So it is anticipated, that further isoelectronic molecules like allenes $\left(\mathrm{R}_{2} \mathrm{CCCR}_{2}\right)$, isothiocyanates (R-NCS), carbodiimides (R-NCN-R), and 


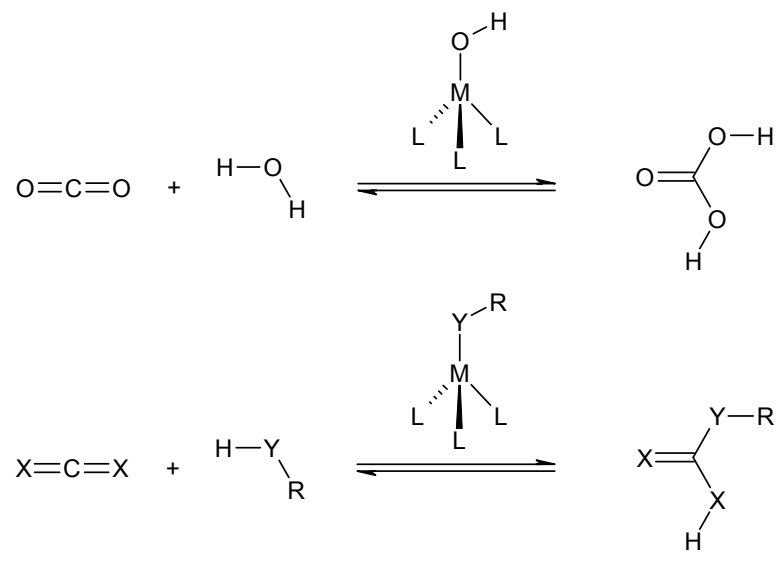

Fig. 7. Catalytical hydration of $\mathrm{CO}_{2}$ as well as the homologous biomimetic addition reaction to heterocumulenes. $\mathrm{X}=\mathrm{CR}_{2}, \mathrm{NR}, \mathrm{O}, \mathrm{S} ; \mathrm{Y}=\mathrm{O}, \mathrm{S} ; \mathrm{R}=\mathrm{H}$, alkyl, aryl; $\mathrm{M}=\mathrm{Zn}^{2+}, \mathrm{Co}^{2+} ; \mathrm{L}=$ ligand

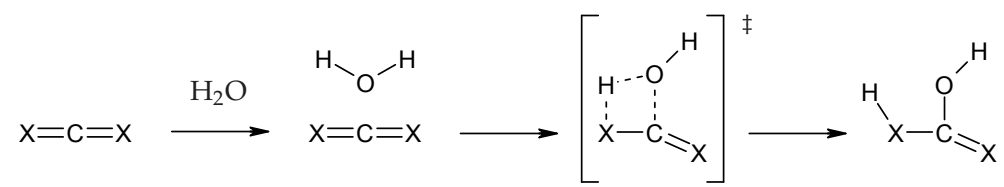

Fig. 8. Uncatalyzed reaction with water across a concerted four-membered cyclic transition state. $\mathrm{X}=\mathrm{CH}_{2}, \mathrm{NH}, \mathrm{O}, \mathrm{S}$

other heterocumulenes should react resembling the mode of action of CA (see Figure 7). In principle, the structure of the adding compound is not restriced to water, as a lot of polar $\mathrm{HX}$ compounds, such as alcohols or $\mathrm{H}_{2} \mathrm{~S}$ and mercaptanes respectively, provide comparable properties. Hence these heterocumulenic structures are very similar, the addition of a HX compound to a heterocumulene catalyzed by a CA model can be written as depicted in Figure 7. In the next sections the reactions of two representatives will be presented.

\subsection{Validation of the Catalytic Effect}

A very important value for estimating the catalytic effect is the activation barrier of the rate determining step in the uncatalyzed reactions. Accordingly to the catalyzed reactions, the uncatalyzed reactions do not differ significantly between various heterocumulenes (see Figure 8). After formation of an encounter complex (EC) between water and the double bond system, a concerted transition state (TS), which normally is the rate determining step of the reaction, has to be surmounted to get to the first intermediates. In some cases, theses intermediates are the final products, in other cases further transition states with minor activation barriers follow.

Depending on the used hetero cumulene, the Gibb's free energies $\Delta G$ of the encounter complexes vary between 0 and $20 \mathrm{~kJ} / \mathrm{mol}$ in comparison to the free non-interacting educts. However, these values might be slightly erroneous, as some DFT methods do not calculate weak intermolecular forces properly. Subsequently, the reaction coordinate leads to a four-membered 


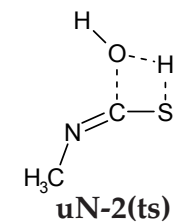<smiles>CN=C1OCS1</smiles>

$\mathrm{uN}-3$ (ts)<smiles></smiles><smiles>CNC(O)=S</smiles>

5<smiles>C=C1COO1</smiles>

uA-2(ts)<smiles>C=C1[CH]OC1</smiles>

uA-3(ts)<smiles>CN=C(O)S</smiles>

3<smiles>CN=C(O)S</smiles>

4<smiles>C=C(C)O</smiles>

6<smiles>C=CCO</smiles>

7

Fig. 9. Transition states and products of the uncatalyzed reaction of MeNCS and allene with water.

cyclic TS (see Figure 9), whose strained structure explains the high activation barrier of the reaction. Typical energy values for these structures can be found in Table 2. The resulting products are also shown in Figure 9. The addition reactions of allene to the products 6 and 7 are both exergonic (see Table 2) and propene-2-ol 6 tautomerizes under standard conditions to the more stable acetone. In case of isothiocyanates, the intermediates are still not exergonic, but after surmounting some minor transition states, several conformers of the exergonic carbamic thio acid can be reached (Eger et al., 2009).

To summarize this, the activation barriers of the uncatalyzed reactions of allenes and isothiocyanates are very high, as they are four-membered cyclic transition states and therefore possess Gibb's free energies between 200 and $300 \mathrm{~kJ} / \mathrm{mol}$. Keeping the estimated activation barriers of carbon dioxide and carbonyl sulfide in mind, it should be possible to see a significant catalytic effect in the reactions of allenes and isothiocyanates.

\subsection{The Selectivity Problem}

Contrary to the case of carbon dioxide, allenes or isothiocyanates as educts for the nucleophilic attack of hydroxide or water provide a more complex scenario. As a heterocumulene, isothiocyanate possess nitrogen and oxygen on the outer positions of the cumulenic system and additionally has an imine group, which reduces the symmetry of the molecule and introduces more reaction possibilities (see Figure 9). Looking at allene, all known problems regarding alkenes and alkynes come to mind, thus chemo- (single or double addition), regio- (Markovnikov- or anti-Markovnikov products) and stereoselectivity (cis- or trans-addition products on stereotopic sides) play a role. For substituted allenes there exists a positional selectivity (Hashmi, 2000) as the attack can take place at two different positions of the allene molecule. Therefore, additions at one of the orthogonal double bonds will lead to constitutional isomers in the case of substituted allenes and as a consequence, this inclusion of regioselectivity doubles the number of isomers.

\section{Isothiocyanates (R-NCS), the Link to Synthesis}

As described previously, the reaction of isothiocyanates with water and other H-X compounds, i.e. alcohols and amines, is kinetically hindered. Water and alcohols do not react 


\begin{tabular}{|c|c|c|c|c|c|}
\hline educt & \multicolumn{3}{|c|}{ MeNCS 1} & \multicolumn{2}{|c|}{ allene 2} \\
\hline $\mathrm{EC}^{\mathrm{a}}$ & \multicolumn{3}{|c|}{$\mathbf{u N}-\mathbf{1}^{\mathrm{c}}$} & \multicolumn{2}{|c|}{$\mathbf{u A}-\mathbf{1}^{\mathrm{d}}$} \\
\hline $\mathrm{TS}^{\mathrm{a}}$ & $\begin{array}{c}\mathbf{u N}-2\left(\text { ts }^{\mathrm{c}}\right. \\
220\end{array}$ & $\begin{array}{c}\mathbf{u N}-3(\mathbf{t s})^{\mathrm{c}} \\
210\end{array}$ & $\begin{array}{c}\text { uN-4(ts) }{ }^{c} \\
206\end{array}$ & $\begin{array}{c}\mathbf{u A - 2}(\mathbf{t s})^{\mathrm{d}} \\
263\end{array}$ & $\begin{array}{c}\mathbf{u A}-3(\mathbf{t s})^{\mathrm{d}} \\
293\end{array}$ \\
\hline$\measuredangle^{1} \mathrm{X}^{2} \mathrm{CR} \mathrm{R}^{\mathrm{b}}$ & $144^{\circ}$ & $142^{\circ}$ & $145^{\circ}$ & $157^{\circ}$ & $142^{\circ}$ \\
\hline$\measuredangle^{1} \mathrm{X}^{4} \mathrm{H}^{3} \mathrm{O}^{\mathrm{b}}$ & $117^{\circ}$ & $123^{\circ}$ & $114^{\circ}$ & $122^{\circ}$ & $121^{\circ}$ \\
\hline$\measuredangle^{2} \mathrm{C}^{3} \mathrm{O}^{4} \mathrm{H}^{\mathrm{b}}$ & $81^{\circ}$ & $74^{\circ}$ & $73^{\circ}$ & $69^{\circ}$ & $70^{\circ}$ \\
\hline$\ltimes^{1} \mathrm{X}^{2} \mathrm{C}^{3} \mathrm{O}^{4} \mathrm{H}^{\mathrm{b}}$ & $7^{\circ}$ & $2^{\circ}$ & $4^{\circ}$ & $0^{\circ}$ & $0^{\circ}$ \\
\hline$\ltimes^{1} \mathrm{X}^{4} \mathrm{H}^{3} \mathrm{O}^{5} \mathrm{H}^{\mathrm{b}}$ & $114^{\circ}$ & $105^{\circ}$ & $105^{\circ}$ & $180^{\circ}$ & $179^{\circ}$ \\
\hline${ }^{1} X^{2} C^{b}$ & $1.716 \AA$ & $1.703 \AA$ & $1.300 \AA$ & $1.386 \AA$ & $1.392 \AA$ \\
\hline${ }^{2} \mathrm{C}^{3} \mathrm{O}^{\mathrm{b}}$ & $1.526 \AA$ & $1.683 \AA$ & $1.629 \AA$ & $1.833 \AA$ & $1.884 \AA$ \\
\hline${ }^{3} \mathrm{O}^{4} \mathrm{H}^{\mathrm{b}}$ & $1.179 \AA$ & $1.269 \AA$ & $1.175 \AA$ & $1.181 \AA$ & $1.190 \AA$ \\
\hline${ }^{1} \mathrm{X}^{4} \mathrm{H}^{\mathrm{b}}$ & $1.724 \AA$ & $1.605 \AA$ & $1.364 \AA$ & $1.449 \AA$ & $1.432 \AA$ \\
\hline producta & 3 & 4 & 5 & 6 & 7 \\
\hline proauct & 49 & 71 & -1 & -92 & -44 \\
\hline
\end{tabular}

${ }^{a} \Delta \mathrm{G}$ in $\mathrm{kJ} / \mathrm{mol}$
${ }^{b} \mathrm{X}^{2} \mathrm{C}$ denote the attacked double bond, with $\mathrm{X}=\mathrm{C}, \mathrm{N}, \mathrm{O}, \mathrm{S}$.
Depending on the selectivity of the reaction the residue $\mathrm{R}$
could be $\mathrm{H}, \mathrm{CH}_{2}, \mathrm{NMe}$ or $\mathrm{S}$ (see formula left).
${ }^{c}$ Calculated at the MP2/aug-CC-pVTZ level of theory
${ }^{d}$ Calculated at the mPW1k/aug-CC-pVDZ level of theory

Table 2. Energies and geometries of the uncatalyzed reaction of methylisothiocyanate and allene with water.

under standard conditions, even when they are heated, it takes very long to see some product (Browne \& Dyson, 1931; Hagemann, 1983; Rao \& Venkataraghavan, 1962; Walter \& Bode, 1967). This is only true as long as there is no acid or base present, which would open up other reaction possibilities. If the catalysis by a CA model is efficient, it would be the method of choice to hydrolyze or alcoholyze isothiocyanate systems under neutral conditions. This might be interesting for the synthesis of complex and acid or base sensitive molecules.

In comparison to carbon dioxide and carbonyl sulfide, isothiocyanates bear a residue on one of the outstanding hetero atoms. As this is an imine function, it increases the degree of freedom and therefore produces more possible pathways.

\begin{tabular}{ccccc}
\hline & & $\mathrm{X}$ & $\mathrm{C}$ & $\mathrm{Y}$ \\
\hline carbon dioxide & $\mathrm{X}, \mathrm{Y}=\mathrm{O}$ & -0.56 & 1.13 & -0.56 \\
carbon oxid sulfid & $\mathrm{X}=\mathrm{O}, \mathrm{Y}=\mathrm{S}$ & -0.48 & 0.50 & -0.01 \\
methylisothiocyanate & $\mathrm{X}=\mathrm{S}, \mathrm{Y}=\mathrm{N}$ & -0.10 & 0.30 & -0.48 \\
allene & $\mathrm{X}, \mathrm{Y}=\mathrm{C}$ & -0.51 & 0.07 & -0.51 \\
\hline
\end{tabular}

Table 3. Natural Charges $\delta^{N C}$ for $\mathrm{CO}_{2}, \mathrm{COS}$, MeNCS, and allene. 

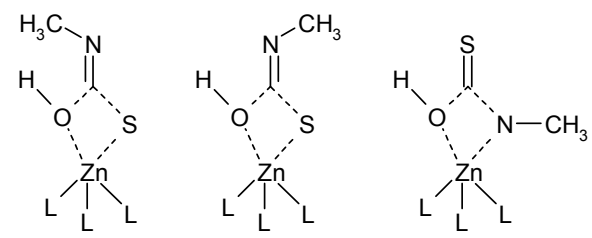

NCS-a(ts); 82 NCS-b(ts); 89 NCS-c(ts); 97

Fig. 10. Rate determining steps in the catalyzed reaction with methyl isothiocyanate. Level of theory is B3LYP /6-311+G(d,p), given values are Gibb's free energies $\Delta G$ in $\mathrm{kJ} / \mathrm{mol}$.

\subsection{Calculated Mechanistic Pathway}

The calculations show only one encounter complex NCS-1, in which the isothiocyanate coordinates via the sulfur atom to two ammonia ligands using hydrogen bridging bonds. Coming from this encounter complex, three different transition states could take place. Whereas in NCS-1(ts) and NCS-2(ts) the $\mathrm{C}=\mathrm{S}$ double bond adds to the $\mathrm{Zn}-\mathrm{O}$ bond, the $\mathrm{C}=\mathrm{N}$ double bond does this in the case of NCS-3(ts) (see Figure 10). These transition states resemble the rate determining steps in the reactions of carbon dioxide and carbonyl sulfide and also are the highest activation barriers in the pathway of isothiocyanate. Contrary to the situation in case of COS, which also possesses an unsymmetric cumulenic system, the energies of this transition states differ not significantly, so a prediction of selectivity depends not only on the energies of the rate determining steps, but also on the further reaction paths and thermodynamic control.

Comparing the free enthalpies of the three transition states and the energies of the following reaction paths, it becomes obvious, that the attack on the $\mathrm{C}=\mathrm{S}$ double bond is thermodynamically and kinetically slightly favored. Contrary to the fact, that the existence of the imine function makes the situation at the rate determining step more complex, it simplifies it at the point, where the Lindskog and Lipscomb transition states enter the scenery right after the attack of the $\mathrm{C}=\mathrm{S}$ double bond. As the disturbed symmetry of isothiocyanate opens up about eight possible pathways, the kinetically and thermodynamically most favorable will be discussed shortly here (see Figure 11).

Structure NCS-2(ts) is the rate determining step, as no other transition state builds up a higher activation barrier. $\Delta G=82 \mathrm{~kJ} / \mathrm{mol}$ relative to the separated educts (ammonia model and methyl isothiocyanate), is not as good as the corresponding values estimated for carbon dioxide and carbonyl sulfide, but it is easily surmountable in a normal experimental environment. The catalytic effect becomes very clear, when comparing the activation barriers of the rate determining steps in the catalyzed and uncatalyzed reaction, as the gap between these values is about $\Delta \Delta G=76 \mathrm{~kJ} / \mathrm{mol}$. This is a significant decrease in energy. The reaction path proceeds further via a Lindskog reaction mechanism (NCS-4(ts)), which is rather lower than the corresponding Lipscomb proton shift. Nevertheless, the pathway surmounting NCS-4(ts) is the thermodynamically and kinetically favored one.

The found selectivity is only true for the reaction with methyl isothiocyanate, as calculation with several residues showed different results. In general, the inductive effect of the residue of the isothiocyanate changes the selectivity. The greater the ability of the residue to pull electrons out of the cumulenic system, the more an attack of the $\mathrm{C}=\mathrm{N}$ double bond is preferred. This is mainly a result of the electronic structure in the cumulenic system. If the residue on the nitrogen atom pulls electron density out of the double bond system, it is mainly taken from 

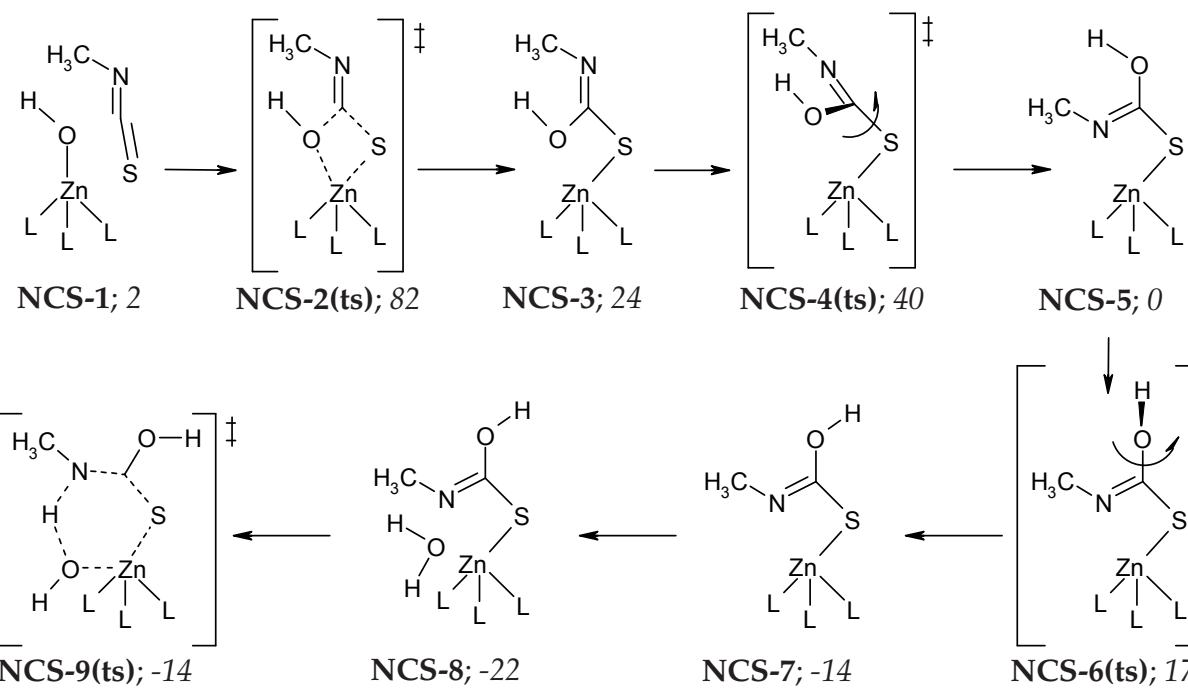

NCS-4(ts); 40

NCS-5; 0

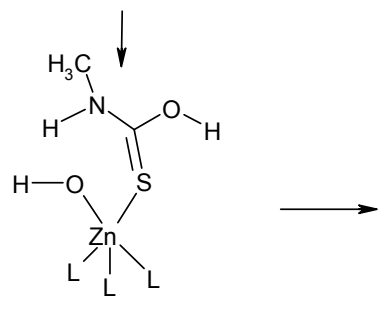

NCS-10;-34

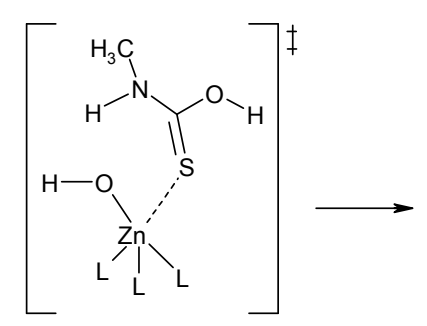

NCS-11(ts); -29<smiles>[3H][Te](Cl)(Cl)(Cl)SC(O)=NC</smiles>

NCS-7; -14

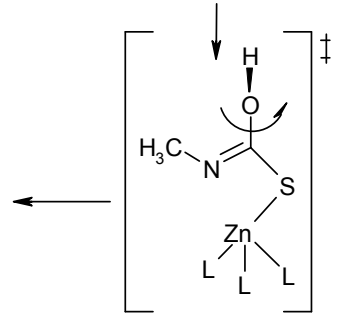

NCS-6(ts); 17

Fig. 11. Pathway of the catalyzed reaction with methyl isothiocyanate. Level of theory is B3LYP / 6-311+G(d,p), given values are Gibb's free enthalpies in $\mathrm{kJ} / \mathrm{mol}$.

the $\mathrm{C}=\mathrm{S}$ double bond. Thus NBO calculations show, that in such cases the $\mathrm{C}=\mathrm{N}$ double bond has a strong triple, and the $\mathrm{C}=\mathrm{S}$ double bond a strong single bond character (Eger et al., 2009). Further calculations with complexes not bearing a hydroxide ion but an hydrosulfide and an thiolate ion respectively, showed, that the biomimetics of CA are not only limited to hydroxide bearing complexes and thus the addition of water to cumulenic system. Furthermore a lot of different combinations of different nucleophiles and cumulenes are possible.

\subsection{Experimental Results}

As the reaction with a thiolate complex reduces the number of possible pathways significantly and those complexes recently proved their ability simulating CA biomimetic insertion reactions (e. g. with carbon disulfide) (Notni et al., 2006), this seems to be a good model complex to see, if isothiocyanate inserts even similar. Thiolate complexes bearing a four-dentate [12] ane $\mathrm{N}_{4}$ ligand are known to work faster than the corresponding three-dentate complexed compounds (Notni, Günther \& Anders, 2007). 


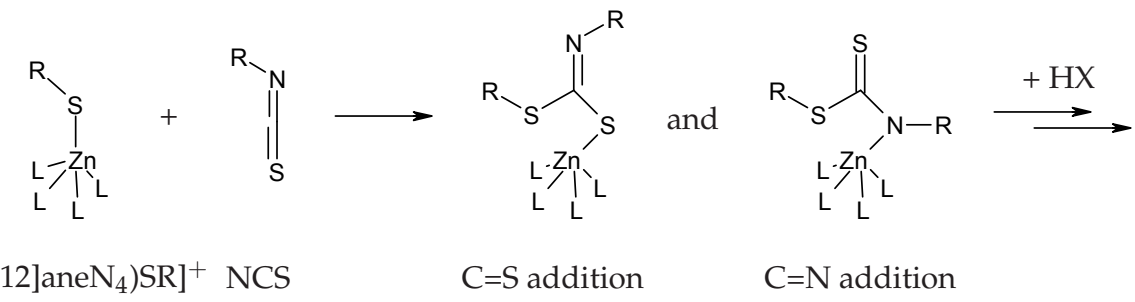

Fig. 12. Insertion possibilities of isothiocyanate to a zinc thiolate complex.

The reaction shown in Figure 12 was carried out in dimethyl sulfoxide under standard conditions at room temperature. The insertion could be proved using GC/MS and Raman spectroscopy. For different isothiocyanates different reaction rates could be determined, as mostly isothiocyanates with an electron withdrawing residue as phenyl or p-nitro phenyl were able to insert easily at room temperature. Depending on the purpose of the reaction those activated cumulenes can react further with an HX compound, e. g. an alcohol or mercaptan.

\section{Allene}

Allene is the simplest hydrocarbon with cumulated double bonds. Since van't Hoff has predicted the correct structures of allene and higher cumulenes, chemists are fascinated by the extraordinary properties like axial chirality of the elongated tetrahedron, if two different substituents at every terminal carbon exist. Allene with its isomer methyl acetylene accrues in large amounts in the C3-cut of the naphtha distillation. Currently both compounds are only hydrated to propene and propane respectively or flared off. Therefore the activation of allene has additionally to the biomimetic a strong economical aspect.

Allene could be estimated as the parent compound for heterocumulenes with two cumulated double bonds. By the formal exchange of one or both terminal carbon atoms a vast number of heterocumulenes are available.

The first investigation of a possible biomimetic activation of allene with zinc catalysts was undertaken by Breuer et al. (1999). They found catalytical activity of zinc silicates with zinc acetate in methanol to give 2-methoxypropene and 2,2-dimethoxypropene in $85 \%$ yield.

\subsection{Calculated Mechanistic Pathway}

The presentation of the whole calculated reaction mechanism of the addition of water to allene goes beyond the scope of this chapter due to the immense number of reaction steps (see (Jahn et al., 2008) for further reading). Therefore the description of mechanistical pathways is confined to the variants of the initial nucleophilic attack, which lead to mechanistical important intermediates. The results show that the initial attack is the rate determining step for the whole catalytic cycle.

The zinc catalyzed addition starts with an encounter complex A-1 between the zinc hydroxide complex and allene. This structure is the starting point for the different reaction variants, comparable to the uncatalyzed reaction described in section 5.1. Corresponding to the regio selectivity problem the attack to allene can take place at either the central or the terminal carbon atom (see Figure 13). The attack of the hydroxide on the terminal carbons leads to a concerted four-membered cyclic transition state A-2(ts) with an activation barrier of $\Delta G=139 \mathrm{~kJ} / \mathrm{mol}$. 


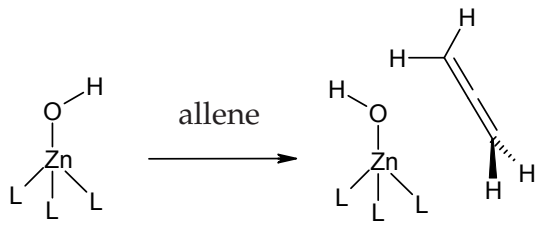

Z

A-1; 15

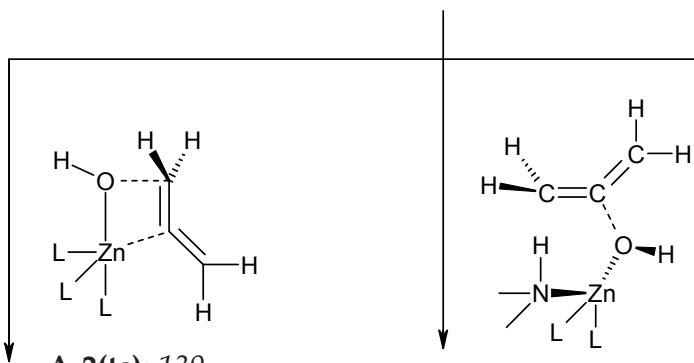

A-2(ts); 139

A-5(ts); 124<smiles>C=[Ge](C(O)[Hg])C(C)(C)C</smiles>

A-3; -20

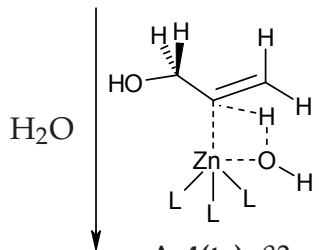

A-4(ts); 82

$$
7 ;-44
$$<smiles>[2H]C=C(O)[Te]([2H])(C)N(C)C</smiles>

AG

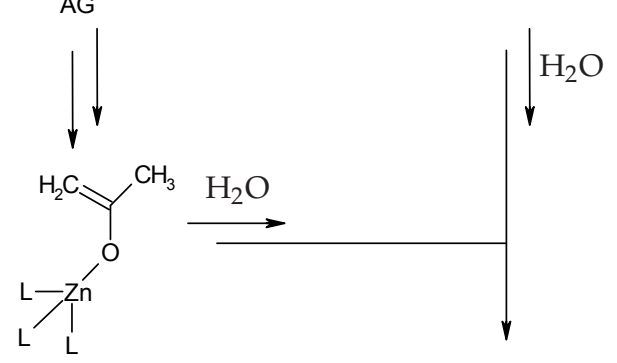

6; -92

A-7; -120

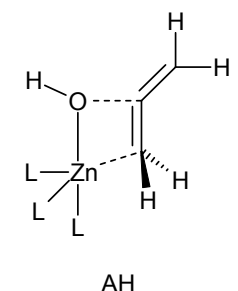<smiles>[3H][Te]([3H])([3H])=C[C@@H]([CH2])O</smiles>

A-9; -57

Fig. 13. Calculated mechanism of the initial, rate determining steps of the activation of allene. $\Delta G$ in $\mathrm{kJ} / \mathrm{mol}$. Level of theory is $\mathrm{mPW} 1 \mathrm{k} /$ aug-CC-pVDZ.

This structure relaxes to the $\mathrm{C}_{2 \mathrm{v}}$-symmetric, slightly exergonic intermediate $\mathbf{A}-\mathbf{3}$, in which the carbon backbone, the hydroxyl group, the metal ion and one nitrogen of the ligand span the symmetry plane. The hydroxyl group is placed between and in front of the ligands. There is only one possibility to close the catalytic cycle starting from intermediate A-3. This mechanism is an attack of a water molecule, which leads to a cleavage of the $\mathrm{Zn}-\mathrm{C}$ bond. One water proton is shifted to the central carbon atom to give allylalcohol 7 and the remaining hydroxide regenerates the catalytic model. 


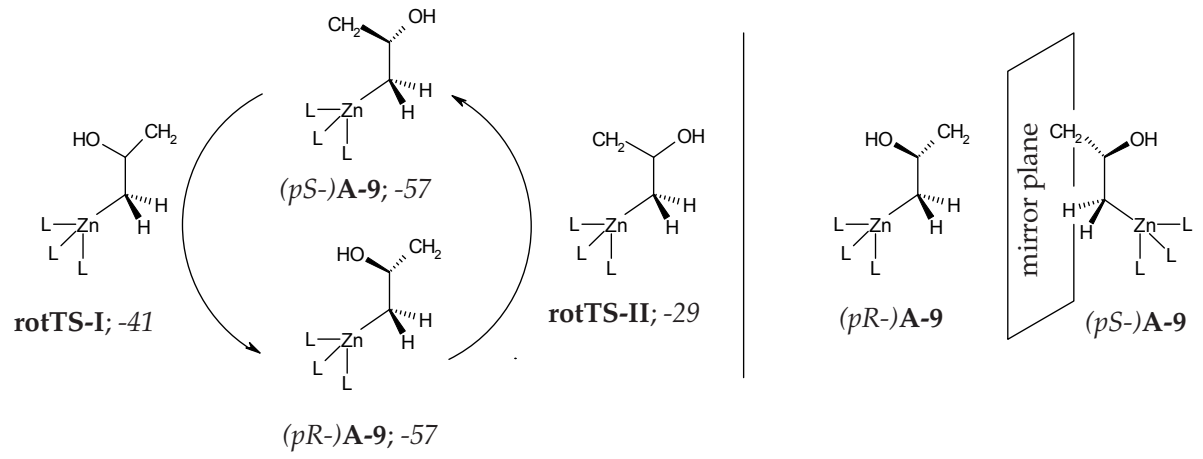

Fig. 14. Mechanism of the racemization of A-9 via $\operatorname{rotTS}-\mathrm{I}$ and $\operatorname{rotTS}-\mathrm{II} . \Delta G$ in $\mathrm{kJ} / \mathrm{mol}$. Level of theory is mPW1k/aug-CC-pVDZ.

Alternatively, the initial nucleophilic attack on the CA model complex can take place at the central carbon atom. Depending on the kind of the model complex, two different mechanisms of the initial reaction step can be found. This reaction path can either proceed via a stepwise or a concerted reaction mechanism, whereas the stepwise mechanism can only be found using the azamacrocyclic models. Contrary, the concerted one can be found in all cases. This shows the restrictions of the ammonia model.

Structure A-5(ts) is the first transition state of the stepwise variant. The activation barrier is $\Delta \Delta G=18 \mathrm{~kJ} / \mathrm{mol}$ ) higher than for the concerted TS A-8(ts), which is interesting, as this TS has no sterical restrictions. As its carbon backbone stands approximatively perpendicular to the $\mathrm{Zn}-\mathrm{O}$ bond, structure A-5(ts) differs fundamentally in its geometry compared to the cyclic concerted TSs. The reaction coordinate is only defined by the difference of the distance between oxygen and the central carbon atom of allene. The TS relaxes to the intermediate A-6. With $\Delta G=113 \mathrm{~kJ} / \mathrm{mol}$ relative to the Gibb's free energy of the separated reactants allene and zinc hydroxide complex, this intermediate is only poorly stable. Intermediate A-6 rearranges by a cascade of proton transfer steps between the substrate and the ligand to the intermediate A-7, which is one of the most stable structures in the calculated reaction path variants $(\Delta G=-$ $120 \mathrm{~kJ} / \mathrm{mol}$ ). Subsequently, the direct formation of acetone is facilitated by a proton shift from an attacking water molecule to the free methylidene group.

The third and most probable transition state between allene and the CA model complex is the concerted four-membered cyclic TS A-8(ts). Comparably to methylisothiocyanate, A-8(ts) resembles the rate determining step in the reactions of carbon dioxide and carbonyl sulfide. A8 (ts) possesses the lowest activation barrier of all three initial TSs $(\Delta G=124 \mathrm{~kJ} / \mathrm{mol})$. It finally relaxes into the intermediate A-9.

Contrary to all other intermediates of different heterocumulenes at comparable points of the reaction coordinate, structure A-9 has an outmost geometry. Whereas in all geometries of intermediates connected to the zinc ion by a heteroatom the former cumulated system and the metal ion are located in a plane, intermediate A-9 has a carbon atom connected to the zinc instead, which forces the plane spanned by the carbon backbone of the allene to stand perpendicular to the $\mathrm{Zn}-\mathrm{C}$ bond and parallel to the plane spanned by the ligand respectively. A reason for that is the partial double bond character of the bonding between the central and the zinc-bound carbon atoms. As a consequence, A-9 is a chiral structure without an asymmetric center and therefore an example of planar chirality. However, the activation barrier of 
the racemization TS is not high enough to ensure a separation of the enantiomers $(p R-) \mathbf{A}-\mathbf{9}$ and ( $p S-)$ A-9 (see Figure 14). Isomerization around the single bond between zinc and the zinc bound carbon can occur clockwise or counter-clockwise. As a result, two rotational transition states exist (rotTS-I and rotTS-II). TS rotTS-I is slightly preferred, as hydrogen bridging bonds between the hydroxyl group and the ligand lower the energy. Comparing their geometries, the proposed analogous transition state for catalytic cycle of the $\mathrm{CO}_{2}$ hydration (Mauksch et al., 2001) and the transition state A-8(ts) are quite similar. In contrast to A-9, the following so-called Lindskog-type intermediate possesses a $C_{2 v}$ symmetry like rotTS-I. The geometry of intermediate A-9 is comparable to the Lindskog-type rotational TS, which leads to the Lipscomb product. The latter is a geometrical equivalent to rotTS-II. Due to the different geometry, an alternative way like the Lipscomb mechanism (proton shift) (Liang \& Lipscomb, 1987; Lipscomb, 1983) appears to be impossible for intermediate A-9.

Intermediate A-9 could be identified as the the key intermediate for the further possible reaction paths. Starting from here, hydrolysis recreates allene and the CA model complex, whereas another pathway directly leads to acetone. The catalytic product of all remaining possible pathways is 6 . Thus the water attack can take place on the methylidene group with and without a preceding rotation of the hydroxyl group. Further, an intramolecular proton shift from the hydroxyl to the methylidene group under generation of a carbonyl and methyl group is another possible pathway. The carbonyl group can also be attacked by a water molecule. Alternatively, a coordination change from the oxygen to the zinc bound carbon can occur. This step generates the stable structure A-7, which is also accessible from the initial stepwise mechanism.

\subsection{Experimental Results}

The reaction of allene and $\left[\mathrm{Zn}\left([12] \mathrm{aneN}_{3}\right) \mathrm{OH}\right] \mathrm{ClO}_{4}$ as the CA model complex was investigated under heterogeneous conditions. Due to the gaseous aggregation state of the unsubstituted allene, a pessure cell was used. The analysis was done with Raman spectroscopic methods.

\section{Conclusion}

In summary, we have shown that the transformation of COS by carbonic anhydrase, which finally yields $\mathrm{H}_{2} \mathrm{~S}$ and $\mathrm{CO}_{2}$, requires no further reactant than water in order to regenerate the most important zinc-bound hydroxide $\left[\mathrm{L}_{3} \mathrm{ZnOH}\right]^{+}$from the hydrosulfide complex. We conclude that $\mathrm{CA}$ is perfectly equipped by nature to perform the task of transformation of $\mathrm{COS}$ into $\mathrm{H}_{2} \mathrm{~S}$. Furthermore, we regard this special function of $\mathrm{CA}$ to be perfectly linked to the plant sulfur metabolism. Therefore, this regeneration mechanism can be regarded as the missing link between CA-catalyzed COS fixation and plant sulfur metabolism; an aspect of fundamental significance for the understanding of some very important biological processes. Nature has chosen an elegant and efficient system for the hydration of $\mathrm{CO}_{2}$ and $\mathrm{COS}$, the $\left[\mathrm{L}_{3} \mathrm{ZnOH}\right]^{+} / \mathrm{CO}_{2}$ or $\mathrm{COS} / \mathrm{H}_{2} \mathrm{O}$ group of reactants. The catalyst is able to transform both cumulenes, though the relative energies of the corresponding reactions steps differ in some details significantly. Further we have shown that it is possible to apply biomimetic principles of high optimized, biochemical processes to the laboratory as well as industrially usable syntheses. The reaction principle of carbonic anhydrase is applicable to other isoelectronic molecules than $\mathrm{CO}_{2}$, which are normally not processed by the enzyme. These biomimetic investigations about the enzyme carbonic anhydrase could serve as a paragon for the further research on biochemical model systems. 


\section{Acknowledgement}

These investigations are part of the general research field of the Collaborative Research Centre Metal Mediated Reactions Modeled after Nature (CRC 436, University of Jena, Germany, since 1997 though 2006 supported by the Deutsche Forschungsgemeinschaft).

\section{References}

Barnett, D. H., Sheng, S., Howe Charn, T., Waheed, A., Sly, W. S., Lin, C.-Y., Liu, E. T. \& Katzenellenbogen, B. S. (2008). Estrogen Receptor Regulation of Carbonic Anhydrase XII through a Distal Enhancer in Breast Cancer, Cancer Research 68(9): 3505-3515.

Bergquist, C., Fillebeen, T., Morlok, M. M. \& Parkin, G. (2003). Protonation and Reactivity towards Carbon Dioxide of the Mononuclear Tetrahedral Zinc and Cobalt Hydroxide Complexes, $\left[\mathrm{Tp}^{\mathrm{But}, \mathrm{Me}}\right] \mathrm{ZnOH}$ and $\left[\mathrm{Tp}^{\mathrm{But}, \mathrm{Me}}\right] \mathrm{CoOH}$ : Comparison of the Reactivity of the Metal Hydroxide Function in Synthetic Analogues of Carbonic Anhydrase, Journal of the American Chemical Society 125(20): 6189-6199.

Bertini, I., Dei, A., Luchinat, C. \& Monnanni, R. (1985). Acid-Base Properties of Cobalt(II)Substituted Carbonic Anhydrases, Inorganic Chemistry 24(3): 301-303.

Bertran, J., Sola, M., Lledos, A. \& Duran, M. (1992). Ab Initio Study of the Hydration of $\mathrm{CO}_{2}$ by Carbonic Anhydrase. A Comparison between the Lipscomb and the Lindskog Mechanisms, Journal of the American Chemical Society 114(3): 869-877.

Blezinger, S., Wilhelm, C. \& Kesselmeier, J. (2000). Enzymatic Consumption of Carbonyl Sulfide (COS) by Marine Algae., Biogeochemistry 48: 185-197.

Bottoni, A., Lanza, C. Z., Miscione, G. P. \& Spinelli, D. (2004). New Model for a Theoretical Density Functional Theory Investigation of the Mechanism of the Carbonic Anhydrase, Journal of the American Chemical Society 126: 1542-1550.

Bowen, T., Planalp, R. P. \& Brechbiel, M. W. (1996). An Improved Synthesis of cis,cis-1,3,5triaminocyclohexane. Synthesis of Novel Hexadentate Ligand Derivatives for the Preparation of Gallium Radiopharmaceuticals, Bioorganic \& Medicinal Chemistry Letters 6(7): 807-810.

Brandsch, T., Schell, F.-A., Weis, K., Ruf, M., Miller, B. \& Vahrenkamp, H. (1997). On the Ligating Properties of Sulfonate and Perchlorate Anions Towards Zinc, Chemische Berichte 130(2): 283-289.

Bräuer, M., Pérez-Lustres, J. L., Weston, J. \& Anders, E. (2002). Quantitative Reactivity Model for the Hydration of Carbon Dioxide by Biomimetic Zinc Complexes., Inorganic Chemistry 41(6): 1454-1463.

Brennan, D. J., Jirstrom, K., Kronblad, A., Millikan, R. C., Landberg, G., Duffy, M. J., Ryden, L., Gallagher, W. M. \& O'Brien, S. L. (2006). CA IX is an Independent Prognostic Marker in Premenopausal Breast Cancer Patients with One to Three Positive Lymph Nodes and a Putative Marker of Radiation Resistance, Clinical Cancer Research 12(21): 64216431.

Breuer, K., Teles, J. H., Demuth, D., Hibst, H., Schäfer, A., Brode, S. \& Domgörgen, H. (1999). Zinksilicate: hochwirksame heterogene Katalysatoren für die Addition primärer Alkohole an Alkine und Allene, Angewandte Chemie 111(10): 1497-1502.

Browne, D. W. \& Dyson, G. M. (1931). CCCCLVII. âĂŤ The Inhibitory Effect of Substituents in Chemical Reactions. Part II. The Reactivity of the Isothiocyano-Group in Substituted Arylthiocarbimides, Journal of the Chemical Society p. 3285. 
Chengelis, C. P. \& Neal, R. A. (1980). Studies of Carbonyl Sulfide Toxicity: Metabolism by Carbonic Anhydrase, Toxicology and Applied Pharmacology 55(1): 198-202.

Chrastina, A., Závada, J., Parkkila, S., Kaluz, S., Kaluzová, M., RajccaronÃąni, J., Pastorek, J. \& Pastoreková, S. (2003). Biodistribution and Pharmacokinetics of ${ }^{125}$ I-Labeled Monoclonal Antibody M75 Specific for Carbonic Anhydrase IX, an Intrinsic Marker of Hypoxia, in Nude Mice Xenografted with Human Colorectal Carcinoma, International Journal of Cancer 105(6): 873-881.

Cronin, L., Greener, B., Moore, M. H. \& Walton, P. H. (1996). Preparations and Structures of Two cis,cis-1,3,5-triaminocyclohexane-Based Complexes Containing HydrogenBonded Solvent Molecules, Dalton Transactions pp. 3337-3339.

Cronin, L. \& Walton, P. H. (2003). Synthesis and Structure of $[\mathrm{Zn}(\mathrm{OMe})(\mathrm{L})]^{*}[\mathrm{Zn}(\mathrm{OH})(\mathrm{L})]-$ *2 $\left(\mathrm{BPh}_{4}\right), \mathrm{L}=$ cis,cis-1,3,5-tris[(e,e)-3-(2-Furyl)acrylideneamino]cyclohexane: Structural Models of Carbonic Anhydrase and Liver Alcohol Dehydrogenase, Chemical Communications pp. 1572-1573.

Dodgson, S. J. \& Forster, R. E., n. (1986). Carbonic Anhydrase: Inhibition Results in Decreased Urea Production by Hepatocytes, Journal of Applied Physiology 60(2): 646-652.

Echizen, T., Ibrahim, M. M., Nakata, K., Izumi, M., Ichikawa, K. \& Shiro, M. (2004). Nucleophilic Reaction by Carbonic Anhydrase Model Zinc Compound: Characterization of Intermediates for $\mathrm{CO}_{2}$ Hydration and Phosphoester Hydrolysis, Journal of Inorganic Biochemistry 98(8): 1347-1360.

Eger, W. A., Jahn, B. O. \& Anders, E. (2009). The Zinc Complex Catalyzed Hydration of Alkyl Isothiocyanates, Journal of Molecular Modeling 15: 433-446.

Eriksson, A. E., Jones, T. A. \& Liljas, A. (1988). Refined Structure of Human Carbonic Anhydrase II at 2.0 ÃĔ Resolution, Proteins: Structure, Function, and Genetics 4(4): 274-282.

Frisch, M. J., Trucks, G. W., Schlegel, H. B., Scuseria, G. E., Robb, M. A., Cheeseman, J. R., J. A. Montgomery, Jr., J. A., Vreven, T., Kudin, K. N., Burant, J. C., Millam, J. M., Iyengar, S. S., Tomasi, J., Barone, V., Mennucci, B., Cossi, M., Scalmani, G., Rega, N., Petersson, G. A., Nakatsuji, H., Hada, M., Ehara, M., Toyota, K., Fukuda, R., Hasegawa, J., Ishida, M., Nakajima, T., Honda, Y., Kitao, O., Nakai, H., Klene, M., Li, X., Knox, J. E., Hratchian, H. P., Cross, J. B., Adamo, C., Jaramillo, J., Gomperts, R., Stratmann, R. E., Yazyev, O., Austin, A. J., Cammi, R., Pomelli, C., Ochterski, J. W., Ayala, P. Y., Morokuma, K., Voth, G. A., Salvador, P., Dannenberg, J. J., Zakrzewski, V. G., Dapprich, S., Daniels, A. D., Strain, M. C., Farkas, O., Malick, D. K., Rabuck, A. D., Raghavachari, K., Foresman, J. B., Ortiz, J. V., Cui, Q., Baboul, A. G., Clifford, S., Cioslowski, J., Stefanov, B. B., Liu, G., Liashenko, A., Piskorz, P., Komaromi, I., Martin, R. L., Fox, D. J., Keith, T., Al-Laham, M. A., Peng, C. Y., Nanayakkara, A., Challacombe, M., Gill, P. M. W., Johnson, B., Chen, W., Wong, M. W., Gonzalez, C. \& Pople, J. A. (2004). Gaussian03.

URL: http://www.gaussian.com

Gibbons, B. H. \& Edsall, J. T. (1964). Kinetic Studies of Human Carbonic Anhydrases B and C, Journal of Biological Chemistry 239(8): 2539-2544.

Glendening, E. D., Badenhoop, J. K., Reed, A. E., Carpenter, J. E., Bohmann, J. A., Morales, C. M. \& Weinhold, F. (2001). Nbo 5.0.

URL: http://www.chem.wisc.edu/nbo5

Hagemann, H. (1983). Methoden der Organischen Chemie (Houben-Weyl): Kohlensäure-Derivate, Vol. E4, Georg Thieme Verlag, Stuttgart. 
Hammes, B. S., Luo, X., Carrano, M. W. \& Carrano, C. J. (2002). Zinc Complexes of Hydrogen Bond Accepting Ester Substituted Trispyrazolylborates, Inorganica Chimica Acta 341: 33-38.

Hashmi, A. S. K. (2000). Neue und Selektive Übergangsmetall-Katalysierte Reaktionen von Allenen, Angewandte Chemie 112(20): 3737-3740. Angew. Chem. Int. Ed. Engl. 2000, 39, 3590-3593.

Hewett-Emmett, D. \& Tashian, R. E. (1996). Functional Diversity, Conservation, and Convergence in the Evolution of the $\alpha-, \beta-$, and $\gamma$-Carbonic Anhydrase Gene Families, Molecular Phylogenetics and Evolution 5(1): 50-77.

Jahn, B. O., Eger, W. A. \& Anders, E. (2008). Allene as the Parent Substrate in ZincMediated Biomimetic Hydration Reactions of Cumulenes, Journal of Organic Chemistry 73(21): 8265-8278.

Jarvela, S., Parkkila, S., Bragge, H., Kahkonen, M., Parkkila, A.-K., Soini, Y., Pastorekova, S., Pastorek, J. \& Haapasalo, H. (2008). Carbonic Anhydrase IX in Oligodendroglial Brain Tumors, BMC Cancer 8(1): 1.

Keilin, D. \& Mann, T. (1939). Carbonic Anhydrase, Nature 144: 442-443.

Kimura, E., Shiota, T., Koike, T., Shire, M. \& Kodama, M. (1990). A Zinc(II) Complex of 1,5,9Triazacyclododecane ([12]aneN $\mathrm{N}_{3}$ ) as a Model for Carbonic Anhydrase, Journal of the American Chemical Society 112(15): 5805-5811.

Kläui, W., Berghahn, M., Rheinwald, G. \& Lang, H. (2000). Tris(pyrazolyl)methanesulfonates: A Novel Class of Water-Soluble Ligands, Angewandte Chemie International Edition 39(14): 2464-2466.

Krishnamurthy, V., Kaufman, G., Urbach, A., Gitlin, I., Gudiksen, K., Weibel, D. \& Whitesides, G. (2008). Carbonic Anhydrase as a Model for Biophysical and Physical-Organic Studies of Proteins and Protein-Ligand Binding, Chemical Reviews 108(3): 946-1051.

Kuhn, U. \& Kesselmeier, J. (2000). Environmental Variables Controlling the Uptake of Carbonyl Sulfide by Lichens., Journal of Geophysical Research - Atmospheres 105: 2678326792.

Kunz, P., Reiß, G., Frank, W. \& Kläui, W. (2003). A Novel Water-Soluble Tripodal Imidazolyl Ligand as a Model for the Tris(histidine) Motif of Zinc Enzymes: Nickel, Cobalt and Zinc Complexes and a Comparison with Metal Binding in Carbonic Anhydrase, European Journal of Inorganic Chemistry 2003(21): 3945-3951.

Lane, T. W., Saito, M. A., George, G. N., Pickering, I. J., Prince, R. C. \& Morel, F. M. M. (2005). Biochemistry A Cadmium Enzyme from a Marine Diatom, Nature 435(7038): 42-42.

Liang, J. Y. \& Lipscomb, W. N. (1987). Hydration of Carbon Dioxide by Carbonic Anhydrase: Internal Protein Transfer of Zinc(2+)-Bound Bicarbonate, Biochemistry 26(17): 5293 5301.

Lindskog, S. (1984). The Kinetic Mechanisms of Human Carbonic Anhydrases I and II: A Computer Approach, Journal of Molecular Catalysis 23(2-3): 357-368.

Lindskog, S. (1997). Structure and Mechanism of Carbonic Anhydrase, Pharmacology \& Therapeutics 74(1): 1-20.

Lipscomb, W. N. (1983). Structure and Catalysis of Enzymes, Annual Review of Biochemistry 52: 17-34.

Lowe, N., Brady, H. J. M., Barlow, J. H., Sowdes, J. C., Edwards, M. \& Butterworth, P. H. W. (1990). Structure and Methylation Patterns of the Gene Encoding Human Carbonic Anhydrase I, Gene 93(2): 277-283. 
Mauksch, M., Bräuer, M., Weston, J. \& Anders, E. (2001). New Insights into the Mechanistic Details of the Carbonic Anhydrase Cycle as Derived from the Model System $\left[\left(\mathrm{NH}_{3}\right)_{3} \mathrm{Zn}(\mathrm{OH})\right]^{+} / \mathrm{CO}_{2}$, ChemBioChem 2: 190-198.

Nakata, K., Uddin, M. K., Ogawa, K. \& Ichikawa, K. (1997). CO 2 Hydration by Mimic Zinc Complex for Active Site of Carbonic Anhydrase, Chemistry Letters 26(10): 991-992.

Notni, J., Günther, W. \& Anders, E. (2007). Zinc Thiolate Complexes [ $\left.\mathrm{ZnL}_{n}(\mathrm{SR})\right]^{+}$with Azamacrocyclic Ligands, Part III: The Influence of the Ligand $L_{n}$ on the Reactivity of Zinc-Bound Thiolate, European Journal of Inorganic Chemistry 7(7): 985-993.

Notni, J., Schenk, S., Protoschill-Krebs, G., Kesselmeier, J. \& Anders, E. (2007). The Missing Link in COS Metabolism: A Model Study on the Reactivation of Carbonic Anhydrase from its Hydrosulfide Analogue, ChemBioChem 8(5): 530-536.

Notni, J., Schenk, S., Roth, A., Plass, W., Görls, H., Uhlemann, U., Walter, A., Schmitt, M., Popp, J., Chatzipapadopoulos, S., Emmler, T., Breitzke, H., Leppert, J., Buntkowsky, G., Kempe, K. \& Anders, E. (2006). Zinc Thiolate Complexes [ZnL $(\mathrm{SR})]^{+}$with Azamacrocyclic Ligands, Part II: Mechanism of the Reaction with $\mathrm{CS}_{2}$, European Journal of Inorganic Chemistry 14(14): 2783-2791.

Parkin, G. (2000). The Bioinorganic Chemistry of Zinc: Synthetic Analogues of Zinc Enzymes that Feature Tripodal Ligands, Chemical Communications pp. 1971-1985.

Parkin, G. (2004). Synthetic Analogues Relevant to the Structure and Function of Zinc Enzymes, Chemical Reviews 104(2): 699-768.

Rao, C. N. R. \& Venkataraghavan, R. (1962). Mechanism of the Addition of Alcohols to Substituted Phenylisothiocyanates: Electrical Effects of the Substituents on the Reaction, Tetrahedron 18(5): 531-537.

Riccardi, D. \& Cui, Q. (2007). $p K_{a}$ Analysis for the Zinc-Bound Water in Human Carbonic Anhydrase II: Benchmark for Multiscale QM/MM Simulations and Mechanistic Implications, The Journal of Physical Chemistry A 111(26): 5703-5711.

Richman, J. E. \& Atkins, T. J. (1974). Nitrogen Analogs of Crown Ethers., Journal of the American Chemical Society 96: 2268-2270.

Ruusuvuori, E., Li, H., Huttu, K., Palva, J. M., Smirnov, S., Rivera, C., Kaila, K. \& Voipio, J. (2004). Carbonic Anhydrase Isoform VII Acts as a Molecular Switch in the Development of Synchronous Gamma-Frequency Firing of Hippocampal CA1 Pyramidal Cells, Journal of Neuroscience 24(11): 2699-2707.

Saito, K. (2004). Sulfur Assimilatory Metabolism. The Long and Smelling Road, Plant Physiology 136(1): 2443-2450.

Sánchez-Méndez, A., Silvestri, G., deÂăJesÃžs, E., deÂălaÂăMata, F., Flores, J., Gómez, R. \& Gómez-Sal, P. (2004). Tris(pyrazolyl)methane Ligands: Syntheses and Structures of Monometallic and Metallodendritic Complexes, European Journal of Inorganic Chemistry 2004(16): 3287-3296.

Sandoval-Soto, L., Stanimirov, M., von Hobe, M., Schmitt, V., Valdes, J., Wild, A. \& Kesselmeier, J. (2005). Global Uptake of Carbonyl Sulfide (COS) by Terrestrial Vegetation: Estimates Corrected by Deposition Velocities Normalized to the Uptake of Carbon Dioxide $\left(\mathrm{CO}_{2}\right)$, Biogeosciences Discussion 2: 183-201.

Schenk, S., Kesselmeier, J. \& Anders, E. (2004). How Does the Exchange of One Oxygen Atom with Sulfur Affect the Catalytic Cycle of Carbonic Anhydrase?, Chemistry - A European Journal 10(12): 3091-3105. 
Schenk, S., Kesselmeier, J. \& Anders, E. (2005). Chemical Modelling of the Uptake Process of Carbonyl Sulphide (COS) by the Enzyme Carbonic Anhydrase, Geophysical Research Abstracts 7.

Schröder, D., Schwarz, H., Schenk, S. \& Anders, E. (2003). A Gas-Phase Reaction as a Functional Model for the Activation of Carbon Dioxide by Carbonic Anhydrase., Angewewandte Chemie International Edition 42: 5087-5090.

Schrodt, A., Neubrand, A. \& van Eldik, R. (1997). Fixation of $\mathrm{CO}_{2}$ by Zinc(II) Chelates in Alcoholic Medium. X-ray Structures of $\left\{[\mathrm{Zn}(\text { cyclen })]_{3}\left(\mu_{3}-\mathrm{CO}_{3}\right)\right\}\left(\mathrm{ClO}_{4}\right)_{4}$ and $[\mathrm{Zn}($ cyclen $) \mathrm{EtOH}]\left(\mathrm{ClO}_{4}\right)_{2}$., Inorganic Chemistry 36: 4579-4584.

Sinnecker, S., Bräuer, M., Koch, W. \& Anders, E. (2001). CS 2 Fixation by Carbonic Anhydrase Model Systems - A New Substrate in the Catalytic Cycle., Inorganic Chemistry 40: 1006-1013.

Sly, W. S., Hewett-Emmett, D., Whyte, M. P., Yu, Y. S. \& Tashian, R. E. (1983). Carbonic Anhydrase II Deficiency Identified as the Primary Defect in the Autosomal Recessive Syndrome of Osteopetrosis with Renal Tubular Acidosis and Cerebral Calcification, Proceedings of the National Academy of Sciences of the United States of America 80(9): 27522756.

Sun, X. C., Li, J., Cui, M. \& Bonanno, J. A. (2008). Role of Carbonic Anhydrase IV in Corneal Endothelial $\mathrm{HCO}_{3}^{-}$Transport, Investigative Ophthalmology and Visual Science 49(3): 10481055.

Tang, C. C., Davalian, D., Huang, P. \& Breslow, R. (1978). Models for Metal Binding Sites in Zinc Enzymes. Syntheses of tris[4(5)-Imidazolyl]carbinol (4-TIC), tris(2Imidazolyl)carbinol (2-TIC), and Related Ligands, and studies on metal complex binding constants and spectra, Journal of the American Chemical Society 100(12): 39183922.

Tautermann, C. S., Loferer, M. J., Voegele, A. F. \& Liedl, K. R. (2003). About the Kinetic Feasibility of the Lipscomb Mechanism in Human Carbonic Anhydrase II, The Journal of Physical Chemistry B 107(43): 12013-12020.

Trofimenko, S. (1966). Boron-Pyrazole Chemistry, Journal of the American Chemical Society 88(8): 1842-1844.

Trofimenko, S. (1967). Boron-Pyrazole Chemistry II. Poly(1-pyrazolyl)-borates, Journal of the American Chemical Society 89(13): 3170-3177.

Urbach, F. L., Sarneski, J. E., Turner, L. J. . \& Busch, D. H. (1968). Nickel(II) Complexes with the Two Isomers of 1,3,5-Triaminocyclohexan, Inorganic Chemistry 7(10): 2169-2171.

Walter, W. \& Bode, K.-D. (1967). Neuere Methoden der Präparativen Organischen Chemie VI. Synthesen von Thiourethanen, Angewandte Chemie 79(7): 285-297.

Yan, J., Jiao, Y., Jiao, F., Stuart, J., Donahue, L. R., Beamer, W. G., Li, X., Roe, B. A., LeDoux, M. S. \& Gu, W. (2007). Effects of Carbonic Anhydrase VIII Deficiency on Cerebellar Gene Expression Profiles in the WDL Mouse, Neuroscience Letters 413(3): 196-201.

Yang, K., Yin, Y. \& Jin, D. (1995). An Active Site Model for Carbonic Anhydrase. Synthesis and Crystal Structure of [[ๆ] $\left.]_{3}-\mathrm{HB}(3-\mathrm{Phpz})_{3}\right] \mathrm{ZnBr}$, Polyhedron 14(8): 1021-1023.

Zhang, X. \& van Eldik, R. (1995). A Functional Model for Carbonic Anhydrase, Inorganic Chemistry 34: 5606-5614.

Zvargulis, E. S., Buys, I. E. \& Hambley, T. W. (1995). Models of the Active Sites of Zinc Containing Enzymes: The Crystal Structures of Two bis(Tripod)zinc(II) Complexes, Polyhedron 14(15-16): 2267-2273. 


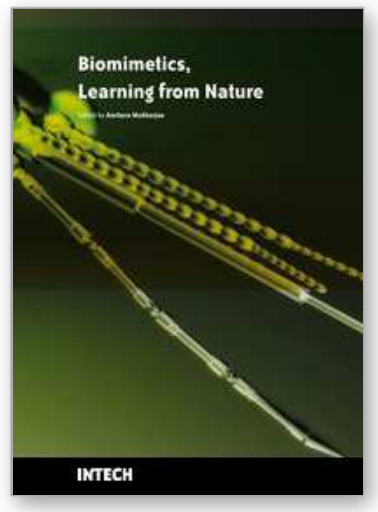

\section{Biomimetics Learning from Nature}

Edited by Amitava Mukherjee

ISBN 978-953-307-025-4

Hard cover, 534 pages

Publisher InTech

Published online 01, March, 2010

Published in print edition March, 2010

Nature's evolution has led to the introduction of highly efficient biological mechanisms. Imitating these mechanisms offers an enormous potential for the improvement of our day to day life. Ideally, by bio-inspiration we can get a better view of nature's capability while studying its models and adapting it for our benefit. This book takes us into the interesting world of biomimetics and describes various arenas where the technology is applied. The 25 chapters covered in this book disclose recent advances and new ideas in promoting the mechanism and applications of biomimetics.

\section{How to reference}

In order to correctly reference this scholarly work, feel free to copy and paste the following:

Burkhard O. Jahn, Wilhelm A. Eger and Ernst Anders (2010). The Carbonic Anhydrase as a Paragon: Theoretical and Experimental Investigation of Biomimetic Zinc-Catalyzed Activation of Cumulenes, Biomimetics Learning from Nature, Amitava Mukherjee (Ed.), ISBN: 978-953-307-025-4, InTech, Available from: http://www.intechopen.com/books/biomimetics-learning-from-nature/the-carbonic-anhydrase-as-a-paragontheoretical-and-experimental-investigation-of-biomimetic-zinc-ca

\section{INTECH}

open science | open minds

\section{InTech Europe}

University Campus STeP Ri

Slavka Krautzeka 83/A

51000 Rijeka, Croatia

Phone: +385 (51) 770447

Fax: +385 (51) 686166

www.intechopen.com

\section{InTech China}

Unit 405, Office Block, Hotel Equatorial Shanghai

No.65, Yan An Road (West), Shanghai, 200040, China

中国上海市延安西路65号上海国际贵都大饭店办公楼405单元

Phone: +86-21-62489820

Fax: $+86-21-62489821$ 
(C) 2010 The Author(s). Licensee IntechOpen. This chapter is distributed under the terms of the Creative Commons Attribution-NonCommercialShareAlike-3.0 License, which permits use, distribution and reproduction for non-commercial purposes, provided the original is properly cited and derivative works building on this content are distributed under the same license. 